\title{
Current Perspectives on Gastrointestinal Models to Assess Probiotic-Pathogen Interactions
}

\author{
Mehreen Anjum, Arja Laitila, Arthur C. Ouwehand and Sofia D. Forssten* \\ International Flavors and Fragrances, Health and Biosciences, Danisco Sweeteners Oy, Kantvik, Finland
}

There are different models available that mimic the human intestinal epithelium and are thus available for studying probiotic and pathogen interactions in the gastrointestinal tract. Although, in vivo models make it possible to study the overall effects of a probiotic on a living subject, they cannot always be conducted and there is a general commitment to reduce the use of animal models. Hence, in vitro methods provide a more rapid tool for studying the interaction between probiotics and pathogens; as well as being ethically superior, faster, and less expensive. The in vitro models are represented by less

OPEN ACCESS

Edited by:

George Grant,

University of Aberdeen,

United Kingdom

Reviewed by:

Sarah C. Pearce,

Agricultural Research Service,

United States Department

of Agriculture (USDA), United States

Nadia Everaert,

University of Liège, Belgium

${ }^{*}$ Correspondence:

Sofia D. Forssten

Sofia.Forssten@iff.com

Specialty section:

This article was submitted to Infectious Agents and Disease,

a section of the journal

Frontiers in Microbiology

Received: 08 December 2021

Accepted: 06 January 2022

Published: 31 January 2022

Citation:

Anjum M, Laitila A, Ouwehand AC and Forssten SD (2022) Current

Perspectives on Gastrointestinal

Models to Assess Probiotic-Pathogen

Interactions.

Front. Microbiol. 13:831455.

doi: 10.3389/fmicb.2022.831455 complex traditional models, standard 2D models compromised of culture plates as well as Transwell inserts, and newer 3D models like organoids, enteroids, as well as organon-a-chip. The optimal model selected depends on the research question. Properly designed in vitro and/or in vivo studies are needed to examine the mechanism(s) of action of probiotics on pathogens to obtain physiologically relevant results.

Keywords: epithelium, gut, in vitro, microbiota, pathogen, probiotic

\section{INTRODUCTION}

The gastrointestinal tract is very complex with a quadruple layered structure; mucosa, submucosa, muscularis mucosa, and serosa. The mucosa can be defined as a layer of epithelial cells situated above the extracellular matrix (ECM)-rich lamina propria. On top of the epithelial cells may be a layer of mucus of varying thickness. The ECM provides physical structure for cells but also mechanical and chemical signals that are essential for different cellular processes (Hussey et al., 2017). The gastrointestinal tract has the highest concentration of microbes and contains an abundant and diverse microbiota distributed differently in the various parts of the system (Walter, 2008). It is a place for host-microbial, as well as bacterial-bacterial interactions and influences the outcome of health or disease (Dieterich et al., 2018). The bacterial interactions may include competition for nutrients and space, but also cross feeding, enabling the development of multispecies co-operation to facilitate mutual survival and growth in the gastrointestinal environment (Montalto et al., 2009). Further, the microbes play an important role in supporting host mucosal immunity and intestinal barrier function. Diet and other environmental factors have a big influence on the gut microbiota, and e.g., the use of fiber can help to maintain a healthy gut microbiota. However, this will not be discussed here further since the focus is on models for probiotic-pathogen interactions.

Different natural mechanisms exist in the host that prevent invasive bacteria from colonizing the host, such as gastric acidity, intestinal motility, destruction of bacteria by intestinal enzymes, bile, and release of immunoglobulin A. Any disturbance in these mechanisms would cause the 
commensal microbiota to change, with a potential increase in the pathogenic microbes causing dysbiosis (Ojetti et al., 2009; Littman and Pamer, 2011). For an infection to occur, the first step is the pathogen's ability to adhere to the mucosal surface and compete with the residing intestinal microbiota (Collado et al., 2007). The commensal bacteria in the gut exclude other microorganisms by competing with them and adhering strongly to the receptor sites present in the intestinal tract, thus limiting the establishment of the incoming potentially pathogenic microbes and preventing infections (Preidis et al., 2011; Bermudez-Brito et al., 2012). Probiotics, defined as "live microorganisms that, when administered in adequate amounts, confer a health benefit on the host" (Hill et al., 2014), are good candidates for preventing gut infections by competing against invading pathogens. The genera Bifidobacterium and Lactobacillus sensu lato contain the most well characterized probiotic strains that are currently commercially available in the market (Fijan, 2014; Brodmann et al., 2017). Furthermore, new species are emerging (Rouanet et al., 2020).

A pathogen is any organism that can produce disease. Different types of pathogens exist, including members of viruses, bacteria, fungi, and parasites. Probiotic strains may compete with pathogens for adhesion to gastrointestinal receptors on epithelial cells and the overlying mucus layer. There are various mechanisms of actions that allow bacterial species to exclude one another such as bacteria-bacteria interactions at the attachment sites on the host-mucosal interface, and/or secretion of antimicrobial compounds, and/or competing for available nutrients (Bermudez-Brito et al., 2012; Plaza-Diaz et al., 2019).

Probiotics may produce antimicrobial compounds (e.g., lactic or other short chain fatty acids, hydrogen peroxide or bacteriocins and low-molecular weight antimicrobial compounds) that can exert a direct effect on pathogens by inhibiting or killing them or by making the environment unsuitable for pathogen survival. Probiotics utilize nutrients and produce organic acids such as lactic acid, acetic, formic and succinic acid as primary metabolites that result in a lowering of the gut $\mathrm{pH}$ causing suppression of pathogen growth (Dicks and Botes, 2010; Bermudez-Brito et al., 2012). The different mechanisms of probiotics' interaction with pathogens and host cells shows the complexity of elucidating these interactions (Figure 1). Moreover, these mechanisms are not only diverse but also mostly strain specific.

Since a probiotic should have demonstrable beneficial effects on the host, methods and techniques that would recreate physiologically relevant in vitro models that can simulate the in vivo environment, are important to study the interactions of commensal bacteria with epithelial cells as well as potential pathogens. The selection of a model must be done based on the hypothesis and mechanism of interest, and the culture conditions, cell types, as well as tools and methods need to be considered to select the most ideal biomimetic model. This review discusses the advantages and limitations posed by various models currently available to study host-microbe interactions within the gastrointestinal tract that can be translated to in vivo research.

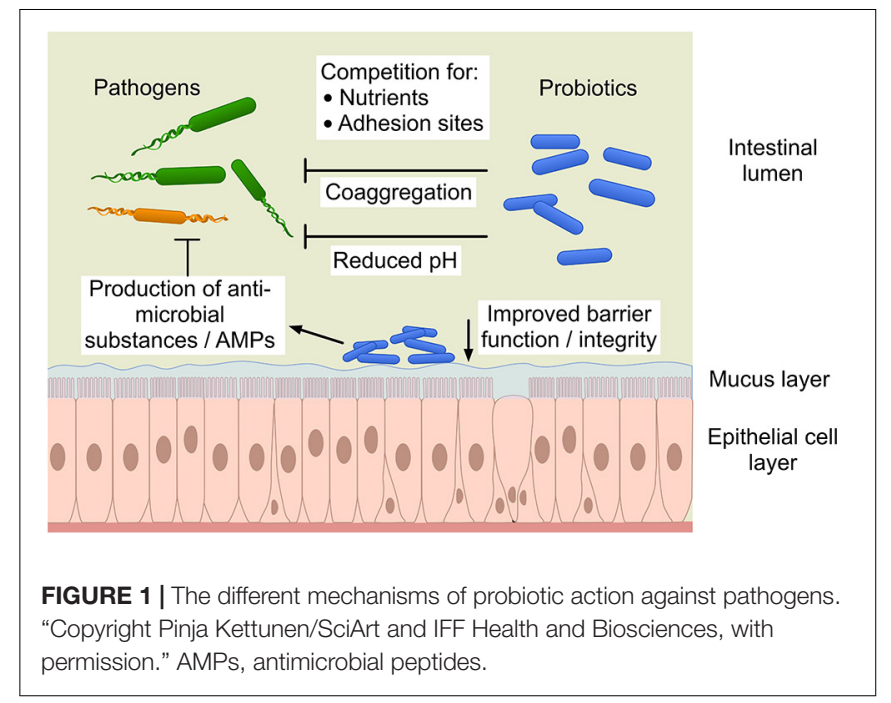

\section{APPROACHES TO STUDY PROBIOTIC-PATHOGEN INTERACTION}

\section{Animal Models}

Animal models provide very controlled environments and enable the use of germ-free animals for investigating the interactions between host and microbe as well as potential pathogens. In addition, animal models provide the possibility to collect samples from different parts of the gastrointestinal tract that are not possible within clinical trials. The in vivo models applied in the probiotic research typically involve vertebrate laboratory animals, most commonly mice and rats. Mice are one of the most frequently used models because their intestinal development is similar to the human intestine and they also have many of the same immune responses and genes (Chinwalla et al., 2002) but some of their intestinal responses to inflammation may differ from human response (Seok et al., 2013). Even though the anatomy of gastrointestinal tract in mice and humans is similar, there are distinctions, e.g., the proportionally larger colon and cecum surface area and taller intestinal villi in mice (Park and Im, 2020). In addition, although the human and mice gut microbiota have 90 and $89 \%$ similarities in phyla and genera (Krych et al., 2013), there are differences in the abundance of microbes; especially lactobacilli and bifidobacteria (Park and Im, 2020). Another widely applied model is rats. Rats being larger than mice provide the advantage of providing larger samples. Mice are easy to breed with short gestation period and have large litter sizes, all of which contributes to their ease-of-use (Nguyen and $\mathrm{Xu}, 2008$ ). These animal models being close to humans genetically and physiologically have some advantages for investigating probiotic-pathogen interaction. However, it is important to consider the similarities and differences between their intestinal microbiota when drawing conclusions. Mice and rats are coprophagic animals which can have an impact on the diet-based intervention (Jiminez et al., 2015). 

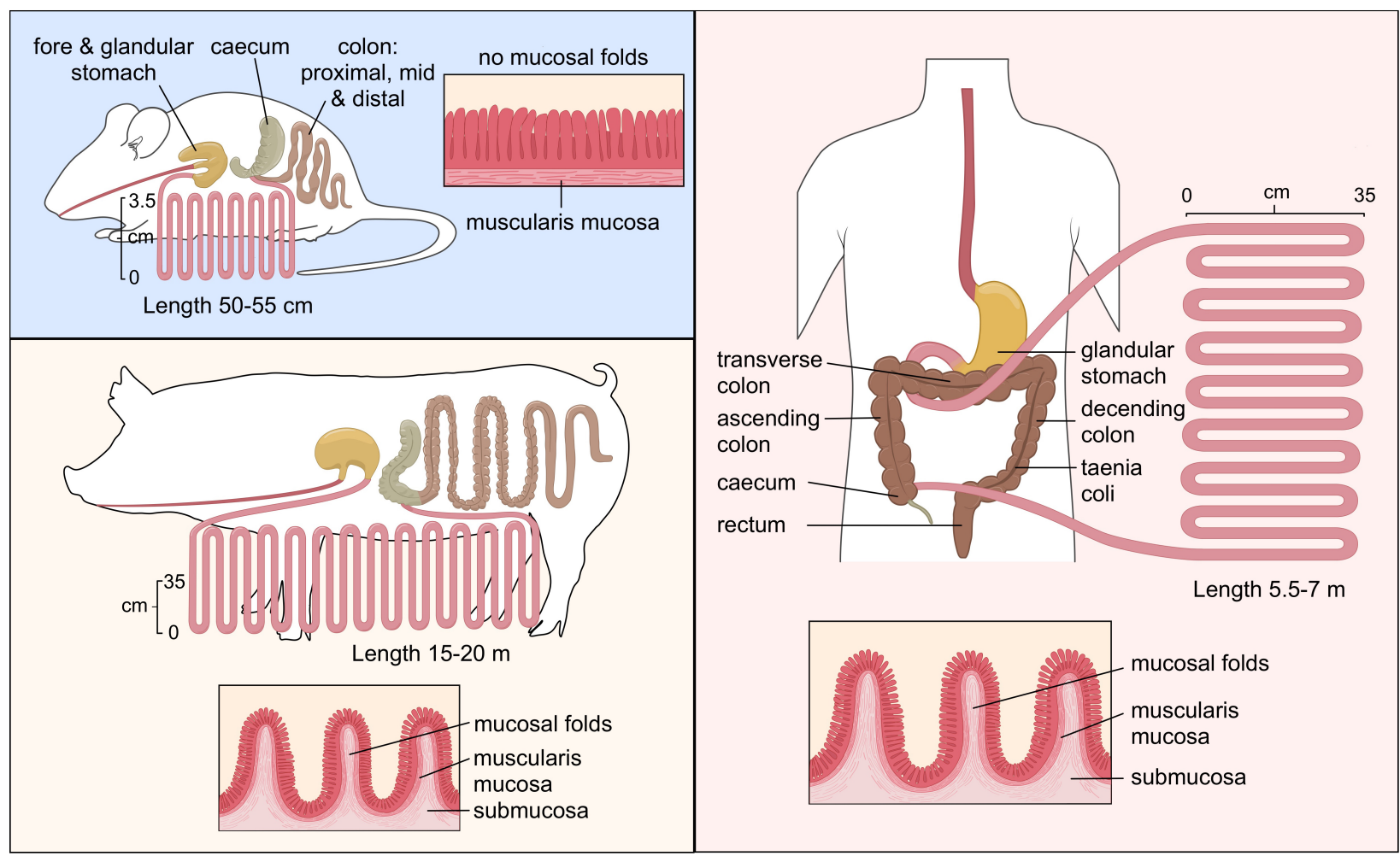

FIGURE 2 | Comparison of the gastrointestinal tract of murine, pig and human. "Copyright Pinja Kettunen/SciArt and IFF Health and Biosciences, with permission."

Another animal model is the pig. While the murine gastrointestinal tract is different from human, the porcine and human intestinal physiology and function are very similar with respect to anatomical and physiological characteristics (Figure 2), including digesta transit times, digestive and absorptive processes (Heinritz et al., 2013; Sciascia et al., 2016). While mice and humans have Paneth cells predominantly in the small intestine, the existence of the Paneth cell in the pig remains disputed (Gonzalez et al., 2013). The Paneth cells contain antimicrobial peptides and immunomodulating proteins that regulate the composition of the intestinal microbiota. However, the digestive enzyme and intestinal microbiota of a pig are comparable to humans which makes them good candidates for studies investigating microbial relationships and diet-based interventions (Patterson et al., 2008). Furthermore, there are big drawbacks as well, such as financial cost of conducting research in these models, the possibility of infection from a potential zoonotic microbes and ethical concerns (Coors et al., 2010).

\section{Alternatives to Animal Models}

There are several ethical concerns connected to the use of animals in research, and the $3 \mathrm{R}$ guiding principles were already described in 1959 for using animals in research and have evolved since then (Tannenbaum and Bennett, 2015). The 3 Rs: replacement, reduction and refinement revolve around the idea of ideally eliminating the use of animal models or decreasing as much as possible as well as treating animals humanely when these models are absolutely needed. In vivo testing of a probiotic strain maybe necessary for scientific and regulatory purposes before the strain can be accepted for widespread use in humans or animals. However, initial screening and selection of probiotic strains, their mechanism of action and health benefits can be studied using the in vitro models.

In vitro models have been developed for the pre-selection of potential probiotic strains due to the difficulties associated with in vivo studies in humans. By using in vitro systems, the physiological and functional properties of microorganisms against pathogens as well as various conditions in the digestive tract such as low $\mathrm{pH}$, pepsin, pancreatic enzymes, bile salts, lysozyme as well as their ability to bind to epithelial cells can be tested (Kos et al., 2003). Table 1 summarizes the advantages and disadvantages associated with the broad categories of in vitro and in vivo models discussed below.

\section{Traditional Methods for Studying Probiotic-Pathogen Interaction}

The antimicrobial activity of probiotics has been mainly studied using the traditional microbiological cultivation assays methods (Silva et al., 2020). The antagonistic activity of probiotics against a pathogen has been determined either through direct bacteria-bacteria interaction or by using cell free supernatant of probiotic bacteria (Fijan, 2016; Piatek et al., 2020). The assay to determine the antimicrobial activity can be performed on 
TABLE 1 | Comparison of the advantage and the limitations of models for studying bacteria-pathogen and bacteria-host interaction.

\begin{tabular}{|c|c|c|c|c|}
\hline Type of model & Examples of models* & Advantages & Limitations & Example references \\
\hline $\begin{array}{l}\text { "Simpler" in vitro } \\
\text { methods }\end{array}$ & $\begin{array}{l}\text { Agar spot test, broth } \\
\text { microdilution, in vitro } \\
\text { biofilms }\end{array}$ & $\begin{array}{l}\text { Fast, inexpensive, high throughput, } \\
\text { easy-to-perform } \\
\text { Flexibility to change parameters easily } \\
\text { Wealth of literature available for } \\
\text { comparison } \\
\text { Standardized protocols across } \\
\text { laboratories } \\
\text { Good for initial screening purposes }\end{array}$ & $\begin{array}{l}\text { Does not represent in vivo responses } \\
\text { Host response is missing } \\
\text { Oversimplified models }\end{array}$ & $\begin{array}{l}\text { Balouiri et al., 2016; Fijan, } \\
2016\end{array}$ \\
\hline 2D models & $\begin{array}{l}\text { Caco-2, HT-29, } \\
\text { HT29-MTX, T84, } \\
\text { IEC-18 and IPEC-J2 } \\
\text { tissue culture cells }\end{array}$ & $\begin{array}{l}\text { Reproducible in lab environment } \\
\text { Easy-to-perform Good for initial } \\
\text { screening } \\
\text { Simple model; well characterized in } \\
\text { literature } \\
\text { Several visualization methods have } \\
\text { been optimized for 2D models }\end{array}$ & $\begin{array}{l}\text { Cell lines mostly derived from cancer } \\
\text { cells, thus different from healthy cells } \\
\text { Does not include most cell types } \\
\text { Hard to culture obligate anaerobes in } \\
\text { co-culture due to oxygen requirements } \\
\text { Grown as monolayer so they lack 3D } \\
\text { structure }\end{array}$ & $\begin{array}{l}\text { McGuckin et al., 2011; } \\
\text { Vergauwen, 2015; Devriese } \\
\text { et al., 2017; Jose et al., } \\
\text { 2017; Yang et al., 2017; } \\
\text { Gharbi et al., } 2019\end{array}$ \\
\hline 3D models & $\begin{array}{l}\text { Organoids (e.g., } \\
\text { enteroids and } \\
\text { colonoids) }\end{array}$ & $\begin{array}{l}\text { Mimics in vivo conditions } \\
\text { Multicellular model } \\
\text { Possibility of long-term cultures } \\
\text { Possibility to investigate cell-cell } \\
\text { interaction }\end{array}$ & $\begin{array}{l}\text { Expensive and requires specialized } \\
\text { expertise } \\
\text { May, need biopsy/tissue samples } \\
\text { Variability between models } \\
\text { Difficult to study obligate anaerobes } \\
\text { because of oxygen requirement } \\
\text { Absence of shear forces and intestinal } \\
\text { peristaltic movements to help cell } \\
\text { differentiation } \\
\text { Require complex media formulation and } \\
\text { supplements }\end{array}$ & $\begin{array}{l}\text { Werner et al., 2016; Costa } \\
\text { and Ahluwalia, 2019; } \\
\text { Bédard et al., 2020; Zhang } \\
\text { et al., } 2020\end{array}$ \\
\hline Chip based models & $\begin{array}{l}\text { Microfluidic and } \\
\text { multi-channel models }\end{array}$ & $\begin{array}{l}\text { Non-transformed cell lines used and } \\
\text { includes all cell types } \\
\text { Patient specific tissue biopsies can be } \\
\text { used to simulate disease conditions } \\
\text { Peristalsis like movement can be } \\
\text { included to enhance cell differentiation }\end{array}$ & $\begin{array}{l}\text { Requires access to tissue biopsies } \\
\text { Expensive, laborious and requires } \\
\text { specialized expertise } \\
\text { Variability between donors Small } \\
\text { sampling size for downstream analysis }\end{array}$ & $\begin{array}{l}\text { Ingber, 2016; Bein et al., } \\
\text { 2018; Sontheimer-Phelps } \\
\text { et al., 2020; Baddal and } \\
\text { Marrazzo, } 2021\end{array}$ \\
\hline $\begin{array}{l}\text { In vitro digestive } \\
\text { models }\end{array}$ & $\begin{array}{l}\text { Fecal batch-culture, } \\
\text { SHIME, TIM, Enteromix, } \\
\text { Reading, PolyFermS }\end{array}$ & $\begin{array}{l}\text { Allow the study of interactions with } \\
\text { intestinal microbiota } \\
\text { Study microbiota from different } \\
\text { populations } \\
\text { Include other models to study host } \\
\text { interaction }\end{array}$ & $\begin{array}{l}\text { No or limited ethical concerns } \\
\text { Usually fecal inoculum } \\
\text { Expensive to run }\end{array}$ & $\begin{array}{l}\text { Minekus, 2015; Van de } \\
\text { Wiele et al., 2015; } \\
\text { Lamichhane et al., 2016; } \\
\text { Piatek et al., } 2020\end{array}$ \\
\hline In silico models & & $\begin{array}{l}\text { Fast forecast of } \\
\text { host-microbiota-probiotic interactions }\end{array}$ & $\begin{array}{l}\text { Only as good as theoretical knowledge } \\
\text { of interactions }\end{array}$ & Geng et al., 2021 \\
\hline Ex vivo models & $\begin{array}{l}\text { InteTESTine, Ussing } \\
\text { chamber, IVOC }\end{array}$ & $\begin{array}{l}\text { In vivo like multilayered structure } \\
\text { Can be used to investigate bacteria } \\
\text { interaction in diseased organs" } \\
\text { Results can be translated to in vivo } \\
\text { conditions }\end{array}$ & $\begin{array}{l}\text { Requires access to human tissue } \\
\text { biopsies and can be difficult to obtain } \\
\text { Costly } \\
\text { Tissues obtained need to be viable and } \\
\text { fresh }\end{array}$ & $\begin{array}{l}\text { Haque et al., 2004; Randall } \\
\text { et al., 2011; Tsilingiri et al., } \\
\text { 2013; Van Krimpen et al., } \\
\text { 2014; Newburg et al., } \\
\text { 2016; Thomson et al., } 2019\end{array}$ \\
\hline Animal models & Mice, rats and pigs & $\begin{array}{l}\text { Physiological model } \\
\text { Allows investigation in the presence of } \\
\text { intact gut microbiota with host cell } \\
\text { interactions } \\
\text { Possibility to conduct long term } \\
\text { investigations } \\
\text { Microbiota can be manipulated through } \\
\text { diet } \\
\text { Innate and adaptive immune response } \\
\text { similar to humans }\end{array}$ & $\begin{array}{l}\text { Ethically concerning } \\
\text { Requires housing and care } \\
\text { In some cases, cannot be translated to } \\
\text { human responses } \\
\text { Expensive experiments }\end{array}$ & $\begin{array}{l}\text { Heinritz et al., 2013; } \\
\text { Jiminez et al., 2015; } \\
\text { Sciascia et al., } 2016\end{array}$ \\
\hline $\begin{array}{l}\text { "Simpler" animal } \\
\text { models }\end{array}$ & $\begin{array}{l}\text { C. elegans, honey bee, } \\
\text { Ciona robusta, fruit fly, } \\
\text { greater wax moth }\end{array}$ & $\begin{array}{l}\text { Relatively fast, inexpensive } \\
\text { Includes host response } \\
\text { May include defined microbiota }\end{array}$ & $\begin{array}{l}\text { Low/no ethical concerns } \\
\text { Simplified host physiology } \\
\text { Simplified microbiota }\end{array}$ & $\begin{array}{l}\text { Vilela et al., 2015; Zanni } \\
\text { et al., 2015; Zheng et al., } \\
\text { 2018; Kumar et al., 2020; } \\
\text { Poupet et al., 2020; Liberti } \\
\text { et al., } 2021\end{array}$ \\
\hline
\end{tabular}

*Please see text for more detailed description of the models. 
solid media (Balouiri et al., 2016) such as the agar spot test (Fijan, 2016). The spot assay may be employed to determine the direct effect by growing the probiotic and pathogen together and the pathogen will be inhibited by the release of inhibiting substance at the start of culture growth. A disadvantage of these cultivation-based methods is that the growth of the probiotic may lead to acidification of the environment and any inhibition observed is attributable to this. Another way is to determine the antimicrobial effect by allowing the probiotic spot to grow on agar media before it is inactivated which is then overlaid with the pathogen mixed in molten agar on top of the probiotic. The antimicrobial activity is determined by calculating the diameter of inhibition area (halo) around the probiotic spot.

A further alternative is the agar well diffusion assay to determine the antimicrobial activity, using cell free supernatants. In this case the pathogen is grown on the agar plate. Small holes of about $6 \mathrm{~mm}$ are punched in the agar which are filled with different concentrations of the cell free supernatant of the probiotic. The antimicrobial activity is measured using the inhibition zone around the well (Parente et al., 1995). The advantage of this method is that the supernatant can be neutralized to avoid the acid effect against the pathogen to study other antibacterial property. Microdilution method is a standardized method for testing antimicrobial activity. Different dilutions of probiotic cell free supernatant of are used in a liquid growth media. A standard inoculum of pathogen is added to it and incubated under appropriate conditions. The broth microdilution method is used to obtain minimal inhibitory concentrations values of the antimicrobial reagent (Balouiri et al., 2016). Convenient as they are, these methods are simplistic in their set up and do not account for the fact that an important ability of the microorganisms is to develop as biofilms (Flemming et al., 2016).

Several in vitro studies have documented the antimicrobial effect of probiotics against various human pathogens. A range of multi-strain probiotic products (Saccharomyces cerevisiae var. boulardii, Lacticaseibacillus rhamnosus GG or Limosilactobacillus reuteri) were screened using traditional plate cultures for studying their antagonistic properties against pathogens such as enteropathogenic Escherichia coli (EPEC), Shigella, Salmonella, Klebsiella pneumoniae, and Clostridioides difficile to support the selection process of products for further clinical evaluation (Piatek et al., 2020). In addition, e.g., the inhibitory effect of probiotic species of Lactobacillus sensu lato against Staphylococcus aureus, Enterococcus faecalis, K. pneumonia, Pseudomonas aerugenosa, and Salmonella typhii have been evaluated (Prabhurajeshwar and Chandrakanth, 2019), as well as Bifidobacterium bifidum, Bacillus, L. reuteri, L. rhamnosus GG, Propionibacterium freudenreichii, Propionibacterium acnes, Lacticaseibacillus paracasei, Lactiplantibacillus plantarum, Lactobacillus bulgaricus, were shown to inhibit pathogens such as S. aureus and K. pneumoniae (Orsi et al., 2014; Lagrafeuille et al., 2018).

A more recent batch fermentation method simulating the distal colon could potentially be used for studying probiotic pathogen interactions, however so far only E. coli Nissle have been tested in this model with simplified communities of gut bacteria (Arcidiacono et al., 2021).

\section{Human Gut Associated Biofilm Models}

It is well established that in most biological systems microbes exist as multispecies biofilm layers instead of single species in free living state. Biofilms are present in the gastrointestinal tract where polymicrobial biofilms naturally grow at the mucosal surface as well as in the lumen as mucin-attached and food particle-attached colonies (Motta et al., 2021). The biofilm formation of probiotic bacteria can be beneficial as it may allow them to survive longer in the intestine and counteract colonization by enteropathogens. Lactic acid bacteria producing bacteriocin have been shown to be good candidates to develop protective biofilms to compete and displace pathogenic bacteria (Gomez et al., 2016; Perez-Ibarreche et al., 2016). Thus, to study and explore mechanisms of bacterial interactions, the experimental systems used in vitro ideally must be able to replicate the biofilm environment (Coenye and Nelis, 2010; Lebeaux et al., 2013). However, there are very few studies focused on screening antibiofilm activity of probiotics and even though some researchers have studied this biological activity of probiotics, their methods and analysis have varied (Cui et al., 2018; Hager et al., 2019; Silva et al., 2020).

Some of the advantages of using in vitro biofilm models are low cost, reproducibility, high throughput investigation and flexibility to obtain conditions that allow growth of the microorganisms being tested. One of the disadvantages of in vitro models is that they represent an oversimplification of the in vivo environment because it is hard to include, e.g., the immune response of the host in vitro. The challenge in co-culturing is to understand how the microbes would behave together as one species may end up outcompeting or even killing the other species, even though they coexist in a natural environment stably. Finding the right growth media and environment that would support simultaneous growth of all species under investigation is challenging. To make things more complicated, it is even more challenging to adjust growth rates in vitro to ensure that one species is not outgrowing the other artificially just because the chosen conditions support its growth more. A further challenge with in vitro multi-species biofilm models, is visualization of one species or its isolation from the complex environment (Coenye and Nelis, 2010; Lebeaux et al., 2013).

The existing biofilm models can be broadly categorized into static and dynamic models (Motta et al., 2021). Static models are closed systems, like microtiter plates, and these are low in cost, flexible and provide high throughput systems. While easy to use, these models are more limited in translation to in vivo environments. In static models the growth media and surface material can be modified to optimize the biofilm formation but since they are closed systems the nutrient supply is limited and metabolites accumulate; thus, they do not allow experiments to be run for long durations. In addition, the surface material used for bacterial adhesion in static models is synthetic, mostly plastic which is not ideal to study infection mechanisms. However, more biologically relevant materials, such as extra cellular matrix proteins, could be used as substratum. 
Many of the biofilm models have been used for oral and wound biofilm formation, but also for some probiotic-pathogen interactions. For example, the formation of Vibrio-biofilm was studied by microtiter plates to which cell free culture supernatant of lactobacilli were applied and hence the biofilm formation of $V$. cholerae was inhibited (Kaur et al., 2018). Some examples of static models that have been used for probiotic-pathogen interactions are multi-well microtiter plates (Gabrilska and Rumbaugh, 2015), the Calgary biofilm device for determination of antibiotic susceptibilities (Ceri et al., 1999) and Agar based static models (Guantario et al., 2018).

In contrast to static biofilm models, dynamic or open-system models provide a continuous supply of nutrients to the microbes in the biofilm (Gabrilska and Rumbaugh, 2015). These models are less cost-efficient than static systems and are not meant for high throughput experiments. Rather, the dynamic models are designed to mimic the actual host environment; thus, nutrients can be provided continuously, and shear forces present in natural conditions, can be modeled. The constant supply of nutrients allows the biofilm formation to survive for longer periods. The shear forces and the material that generates them can define the development of the biofilm by affecting the physical and chemical properties. However, these models have not been used to study probiotic-pathogen interaction in the gastrointestinal tract, more for, e.g., oral cavity (Salli et al., 2017) and urinary tract (Azevedo et al., 2017) environments.

\section{Two-Dimensional Intestinal Cell Models}

Nearly all two-dimensional (2D) cultures are dependent on adhesion and thus cannot be grown in suspension cultures without mechanical support. Different cell lines such as primary or transformed cells can be used for $2 \mathrm{D}$ cultures, and cell lines like Caco-2 (Jose et al., 2017), HT-29 (Gharbi et al., 2019) and T84 (Devriese et al., 2017) have been used to understand bacterial survival and replication as the cells provide the hostlike intestinal microenvironment. The small and large intestine have critical roles in the absorption of nutrients as well as house a large part of the human microbiome. During the past decade, $2 \mathrm{D}$ model systems comprised of culture plates as well as Transwell inserts have attempted to recapitulate the complex, in vivo intestinal physiology using cell lines derived from intestinal tumors instead of primary epithelial cells. In order to decide which cell lines to use, certain factors should be assessed, such as the culture condition required, media preparation, differentiation of cells needed, number of passages required and the expression of genes and proteins needed for the investigational purpose. There are advantages and disadvantages of using some of the most used cell lines in research and that will be discussed forthwith.

The classical static culture system mainly generating adherent $2 \mathrm{D}$ cell monolayer has several advantages; they are easy to maintain and the results derived are reproducible and consistent (Duval et al., 2017). Transformed or immortalized cell lines have been used extensively as they are cost-effective and enduring models. These cell lines can be passaged indefinitely and have been utilized extensively to perform preliminary screening and mechanistic studies. In addition, high throughput screening and imaging techniques are available, although in vivo characteristics may not be represented accurately (Joshi et al., 2019). It is the simplicity and efficiency of $2 \mathrm{D}$ cell lines that have made them so popular for in vitro studies (Bédard et al., 2020). On the other hand, primary cell lines are often considered to be more biologically and physiologically similar to the in vivo situation (Shamir and Ewald, 2014).

The disadvantage of using immortalized cell lines is that they cannot mimic the actual infection process completely as they lack the complexity of all cell types present in vivo as well as the immune responses (Finlay and Brumell, 2000). Since the cell responses are different, it also affects biochemical and biomechanical properties of cells (Edmondson et al., 2014). The $2 \mathrm{D}$ cultures of immortalized cells only have one cell type, making it difficult to mimic the complex architecture of the in vivo mucosa. This lack of cellular complexity compared to in vivo conditions is a serious disadvantage of 2D models available.

Even though the 2D cell models have been in use for decades, yet there is not a standardized in vitro model that has incorporated non-cancerous cell lines to study healthy large intestine response to bacterial interaction, which makes translation of response to healthy individual difficult. Thus, so far, the models applied do not have the ability to incorporate a complex bacteria community and have hence been usually used for investigating single bacterium-host interaction. Cells are grown on flat surfaces which causes them to behave differently as it leads to an unnatural polarity on the apical and basal surfaces of the cells which is especially an issue for cells that are non-polar in vivo (Bédard et al., 2020).

One challenge with cell models, is co-culturing of probiotic or intestinal bacteria and intestinal epithelial cells since the cells require aerobic conditions, while many of the bacterial strains require anaerobic conditions (Kim et al., 2010; Shin et al., 2019), although some recent efforts have been made to improve coculturing (Shin et al., 2019; Sasaki et al., 2020).

Caco-2 cells grown as confluent monolayers have been used to investigate absorptive and transport kinetics under basal and bacteria exposed conditions. The disadvantage of using Caco- 2 cells is that they originate from cancer cells and they lose their original characteristics during long culturing processes forming derivative cells (Foulke-Abel et al., 2014; Hoarau-Véchot et al., 2018). They are also unable to produce similar level of mucin under lab conditions as in vivo (Pan et al., 2015). However, one option is to incorporate a mucin layer to the Caco-2 cells monolayer which in some studies gave a better approach to the in vivo physiological characteristics (Santbergen et al., 2020).

More than 200 research papers have applied Caco-2 models to study intestinal barrier function and bacterial adhesion and invasion properties (Pearce et al., 2018). The protective role of different lactobacillus species, e.g., L. rhamnosus GG and L. casei against inflammation (Toki et al., 2009), and L. plantarum against C. sporogenes and E. faecalis adhesion (Ramiah et al., 2008) have been evaluated by using Caco- 2 models. The challenge here is that tissue culture cells require aerobic conditions while many bacteria require anaerobic conditions; further, simulation of the intestinal environment would require anaerobic or microaerobic conditions. Chip based models may be better suited to simulate 
this; see below (Jalili-Firoozinezhad et al., 2019; Poceviciute and Ismagilov, 2019).

Another popular cell line that contains a mucus layer is HT-29. HT-29 cells have similar drawbacks as Caco-2, as they also are transformed cells derived from colon cancer cells. In addition, HT-29 cells are unable to form proper tight junctions thus, cannot be used to study barrier function (Schoultz and Keita, 2020), However HT29cl.f8, derived from a single cell of HT29 display important characteristics for permeability studies such as microvilli, tight junctions and a high transepithelial/transendothelial electrical resistance (TEER) (Mitchell and Ball, 2004). Hence, this clone can be an alternative to model the intestinal barrier (Sun et al., 2019).

By treating HT-29 cultures with methotrexate, mucussecreting cells (HT29-MTX) have been obtained (McGuckin et al., 2011), and these cells exhibit entirely differentiated goblet cell-like phenotype and secrete low amounts of mucin (MUC2) that is predominantly expressed in the small and large intestine. The HT29-MTX cell model has more physiologically relevant characteristics because of the mucus layer formation than the HT-29, and may thus be better suited for studying cellspathogen/probiotic interactions (Gagnon et al., 2013). Bacterial adhesion to the epithelium can be studied by using HT-29 cells that contain mucus-producing goblet cells in Transwell system with apical and basolateral polarity (Altamimi et al., 2016). HT29 cells have also been used to study the inhibitory effect of Lactobacillus acidophilus NCFM, L. rhamnosus and L. casei on intestinal pathogens like Salmonella and E. coli (Toki et al., 2009; Meng et al., 2017).

To obtain more physiologically and functionally relevant results for probiotic-pathogen interactions, co-cultures of Caco2 and HT-29 cells can be used. However, this model has more commonly been used for studying adhesion properties of probiotic strains rather than probiotic-pathogen interactions. One study using co-culture exposed the cells to Streptococcus thermophilus and L. acidophilus and as a result the barrier function of the cell monolayer was enhanced and provided protection against invasion and adhesion of enteroinvasive E. coli (EIEC) (Resta-Lenert and Barrett, 2003).

A non-transformed cell line IEC-6 that originates from epithelial cells of small intestine from Rattus norvegicus (rat) are an example of healthy cell type. A drawback of these cell lines though is that they do not depict a similar metabolic or absorptive response as human cells including the colon physiology. Hence, the interaction of bacteria to epithelium is different which makes translation of research conducted in these cell lines to human response difficult. The IEC-6 have more been used to study the effect of probiotics on different conditions like necrotizing enterocolitis (NEC), stress (Khailova et al., 2010) or (lipopolysaccharide) LPS (Liu et al., 2010) rather than probiotic-pathogen interactions. In one study investigating probiotic-pathogen interaction, 6 LABs were shown to inhibit E. coli, Salmonella enterica, S. aureus, Pseudomonas brenneri, C. difficile, and Bacillus subtilis (Guan et al., 2020).

T84 is another cell line derived from cancer cell lines and grown as monolayer posing same disadvantages as aforementioned cell lines. However, T84 has been shown to have high TEER properties which makes them good model to study effects of microbes on epithelial barrier function. In addition, T84 monolayers have been shown to be superior to Caco-2 as a model system of colonocytes (Devriese et al., 2017). EIEC, EPEC and enterohemorrhagic E. coli (EHEC) studies have used T84 cells for investigating the protective effect of probiotic strains against invasion or epithelial injury caused by pathogenic E. coli (Sherman et al., 2005; Khodaii et al., 2017).

Another cell line derived from epithelial cells from the rat small intestine, IEC-18, was used to show the protective effect of bifidobacteria against pathogenic invasion of enteropathogenic E. coli by improving the intestinal barrier function (Yang et al., 2017).

IPEC-J2 cells are unique since they are derived from small intestinal cells (porcine origin), and most similar to humans as compared to other animal cell lines. IPEC-J2 are not transformed and mimic the normal intestinal physiology and function, and is a multi-cellular cell line with mucus producing cells that can be used for studying interactions with enteric bacteria or effects of probiotics (Vergauwen, 2015). IPEC-J2 cells have for, e.g., been used in an adhesion study, where adhesion properties of 11 Lactobacillus sensu lato strains were studied and L. reuteri and L. plantarum were shown to display the highest adhesion capacity to IPEC-J2 (Larsen et al., 2009).

Instead of cells in 2D models, mucus and extra cellular matrix proteins can be used as a substratum. Immobilized mucus may provide a better representation of the intestinal mucosa than some intestinal epithelial cells; under normal conditions intestinal microbes do not interact with the epithelium, but with the overlying mucus layer. Immobilized extra cellular matrix proteins may be used as a model for damaged tissue. The models have been successfully used to study the interaction between commercial probiotics and enteric pathogens (Collado et al., 2007). Since the normal intestinal epithelium consists of several different cell types like enterocytes, goblet cells, stem cells, enteroendocrine cells, and $\mathrm{M}$ cells a that are not accurately represented in 2D cell models, thus the three dimensional and organ-on-a-chip systems were developed that will be discussed later (Dutton et al., 2019).

\section{Three-Dimensional Cell Models of the Human Gut}

To mimic the dynamic interactions between different players in the gut more realistically, different three-dimensional (3D) models have been developed where the cells are surrounded by extracellular matrix (ECM) that contains soluble factors, nutrients and oxygen with apical basal polarity similar to in vivo organization of cells. Thus, 3D systems can be used to recreate more accurate disease models (Ringuette Goulet et al., 2017; Bourland et al., 2018).

The term organoid ("organ-like") has been used to describe a variety of $3 \mathrm{D}$ models that resemble in vivo tissues. The term intestinal organoid has been used in broad and unspecific manner, while organoids can be referred to as "enteroid" when the cells come from the small intestine and "colonoid" when cells are derived from colon (Stelzner et al., 2012). Organoids 
represent an attractive, physiologically relevant tool that are derived from intestinal stem cells differentiate into intestinal epithelium, mesenchyme, and lumen-like structures to form spherical structures forming spheres (Spence et al., 2011). With $3 \mathrm{D}$ culture system, it is possible to partially recapitulate the complexity of mammalian organogenesis in vitro, for example by using pluripotent stem cells (PSCs), derived from embryonic stem cells (ESCs) or induced pluripotent stem cells (iPSCs) (Werner et al., 2016).

The Rotating wall vessels (RWV) have enabled prolonged $3 \mathrm{D}$ culture of both cell lines and primary cells and bacterial populations and have been used for studying host- pathogen interactions. This device produces a laminar flow to enable the growth of intestinal organoids in suspension culture in conjunction with bacteria to simulate an enteric infection in a fluidic setting. However, the specific 3D surface topography of the intestine has been poorly recreated which is important for studying host-pathogen interactions (Barrila et al., 2010).

Several recent reviews have detailed the method used to generate different 3D models and the challenges involved with those techniques (Costa and Ahluwalia, 2019; Bédard et al., 2020; Zhang et al., 2020). Organoid cultures have 3D structures with villus like domains that retains cellular polarization toward tissue, and because their cells can express intestinal stem cell markers, they differentiate into all epithelial cell lineages. In short, organoids can be ever-expanding, and retain their original organ identity (Sato and Clevers, 2013). The development in organoid models has been moving quite fast and the use for organoids ranges from investigations in regenerative medicine (Wiegerinck et al., 2014) to host-microbe interaction studies (Lukovac et al., 2014) and disease modeling (Baumann, 2017). The major criticism of classical 2D cell culture systems was their inability to create the in vivo -like conditions ideally, which led to development of $3 \mathrm{D}$ systems. The $3 \mathrm{D}$ systems were developed with the intention of replacing animal models whenever possible, so efforts are being made to recreate as realistic models as possible (Bédard et al., 2020). However, these organoids are not appropriate to study epithelial layer maintenance that is not spherical, and it is not possible to include various stem and differentiated cell types that are present in the native intestinal tissue. The monolayer structure can be used in conjunction with other cells such as immune cells or bacteria and may also be used to study responses to different apical stimuli (Ettayebi et al., 2016; Braverman and Yilmaz, 2018). The 3D architecture is lost in this system which is the downside of using these monolayers.

Despite being advanced models, the organoids have limitations that include the ethical aspect of using live human derivatives, lack of consistency and quality control in the individual sample collected, and it is not easy to determine which factor elicited the response because of complex environment. They form closed lumen with apical side of lumen inside that is inaccessible from outside thus, they cannot be used to study the interaction of microbes with the cells (Hill et al., 2017; Bein et al., 2018) unless microinjection technique is used. Williamson et al. (2018) used a high-throughput microinjection device to inject fecal derived microbial community efficiently and reproducibly into the lumen of gut organoid. They also showed that complex microbiota communities could be transferred into the lumen and cultured for up to 4 days without changes in the microbial composition. Using the microinjection technique, Freire et al. (2019) added butyrate, lactate and polysaccharide A into the duodenal biopsies from celiac disease patients which lead to improved barrier function. While this technique opens opportunity for investigation of complex microbial communities within $3 \mathrm{D}$ models, microinjection technique is not easy to perform and may cause damage to the organoid structure (Heo et al., 2018). Another option is to use mechanical shearing to promote the solubilization of the semi-solid spherical structure and which can generate a polarized epithelial layer in Transwell chambers followed by microbe addition (Dutta et al., 2017; Hill et al., 2017). Using Transwell chambers also allows studying the barrier function by TEER measurement. It should be noted though that dissociating 3D models prior to infection, would disconnect their form and function causing them to lose certain phenotypes, although they may re-associate into $2 \mathrm{D}$ on a polarized monolayer, with similar cell types, and even a semi-3D structure that resembles intestinal folds (Braverman and Yilmaz, 2018; Kar et al., 2021). Another way to overcome the challenges to access the apical side within spheroid organoids or enteroids (Co et al., 2019) is to use a method to reverse the epithelial polarity of the enteroids so that the apical surface faces outward. Hence, no need for microinjection since microbes can be directly added to the culture media to interact with the apical enteroid surface.

Compared to $2 \mathrm{D}$ models there are limited number of studies involving bacteria interactions with host, particularly probiotic strains in 3D cell models. Most of the studies involving microbes have so far focused studying pathogenesis (Forbester et al., 2015; Leslie et al., 2015; Karve et al., 2017). An immensely useful technique was recently published in which the researchers have reversed the organoid polarity so that the apical surface faces the media (Co et al., 2019). This model can be used to study barrier integrity, nutrient uptake and allows us to study the microbiomehost epithelium interaction in response to diet or metabolite addition (Rubert et al., 2020). However, this approach can only be used for aerobic bacteria or for cell free supernatant from strict anaerobes.

Enteroids have been used to study host response to pathogens such as Enterohemorrhagic E. coli (In et al., 2016), enterotoxin producing E. coli (Rajan et al., 2020) and even cholera-toxin (Zomer-van Ommen et al., 2016). Aoki-Yoshida et al. (2016) used murine intestinal enteroids to study the effect of L. rhamnosus GG. Some commensal bacteria used in conjunction with enteroids include Akkermansia muciniphila and Faecalibacterium prausnitzii (Lukovac et al., 2014), however they used the supernatants of these commensal bacteria. Han et al. (2019) used human organoids to demonstrate the protective effect of L. rhamnosus GG to epithelial barrier dysfunction. They used fecal supernatants from intestinal bowel syndrome patients to induce barrier damage. L. reuteri D8 was shown to repair the epithelial damage caused by TNF- $\alpha$ treatment in the coculture of mouse intestinal organoids and human lamina propria lymphocytes, leading to improved intestinal barrier function and epithelial layer proliferation (Hou et al., 2018). Interaction of 
non-pathogenic strain of $E$. coli with cells in organoids derived from human intestinal stem cells showed stable host-microbe symbiosis that lead to improved epithelial barrier (Hill et al., 2017). The anti-cancer activity of L. fermentum was compared in $3 \mathrm{D}$ vs. $2 \mathrm{D}$ cell model and it was concluded that the $3 \mathrm{D}$ models are more appropriate for studying anti-cancer benefits of probiotic strains (Lee et al., 2019). While this is not a probiotic-pathogen interaction study it directly compares the effects of a probiotic strain in $2 \mathrm{D}$ vs. $3 \mathrm{D}$.

$3 \mathrm{D}$ cultures that arrange themselves during proliferation into sphere-like formation, are called spheroids. Caco-2 spheroids were found to be a good model for getting broad information on the possible interaction mechanisms between host and bacteria of importance for food safety when used for evaluation of the adhesion/invasion ability of Lactobacillus sakei 1 and Listeria monocytogenes (Pereira et al., 2021). Gastric dendritic cells control the adaptive response to Helicobacter pylori infection and when spheroid cultures of primary gastric epithelial cells have been infected with $H$ pylori to study the response of the gastric epithelium (Sebrell et al., 2019), thus it could also be used for studying probiotics.

Recently another in vitro $3 \mathrm{D}$ model for culturing human gut microbiota and for assessing the production of stable and long-lasting biofilms was developed. The model consists of a biofabricated electrospun structure of gelatin where human fecal microbiota can be cultured on the scaffolds and the microbial biofilm can be monitored and quantified over time (Biagini et al., 2020).

A further model is HuMIX (human-microbial crosstalk); a sophisticated multi-channel model using co-culture of Caco2 cells with L. rhamnosus GG or Bacteroides caccae (microbes cultured under anaerobic conditions), with which it was shown that the two microbial species generated different metabolic and immune responses (Shah et al., 2016). On the downside, the model has two separate chambers for intestinal and microbial cells with a thin membrane separating the two channels and there is no pulsatile flow unlike, e.g., in the microfluidic "Gut-on-aChip" (Kim and Ingber, 2013).

\section{Microphysiological/Chip-Based Models of the Gastrointestinal Tract}

One of the most recent advances in in vitro intestinal cell models is organs-on-a-chip. These microfluidic based models mimic complex multi-organ and multi-layered systems in vivo and enables the exploration of pathophysiological features of human microbial infections (Baddal and Marrazzo, 2021). The structural and functional integrity can be maintained for many days allowing for experimental designs that explore change in biological response over a period (Barrila et al., 2018). Several human gut-on-chips models have been developed to better mimic the complexity of the in vivo intestinal epithelium (Kim et al., 2012, 2016a,b; Kasendra et al., 2018). However, only some guton-chip models, e.g., by the Wyss Institute have incorporated microbes for studying specific interactions of bacteria with host cells. This microfluidic model stimulates the formation of villuslike structures by Caco- 2 cells and can be combined to simulate exposure to microbes and human cells in a simulated sub mucosa (Bein et al., 2018). The model maintains aerobicity for the tissue culture cells while the microbes are in an anaerobic environment; thus, better mimicking the intestinal situation better than traditional 2D tissue culture models. This way changes in microbial response due to certain stimuli can be studied; which bacteria are metabolically dominant or what is the transcriptional profile of microbes in response to cell stimuli (Jalili-Firoozinezhad et al., 2019; Poceviciute and Ismagilov, 2019).

The advantages of organ-on-chips include a $3 \mathrm{D}$ environment that mimic tissue structure and incorporates cells lines or stem cells. They exhibit in vivo like properties and cells are able to differentiate into specialized cell types. The chips are microfluidic systems that allow simulation of cellular microenvironment (Ingber, 2016). However, they are laborious and require substantial expertise before they can be used. They are technically challenging and utilize small volumes and cell numbers. The methods developed so far to perform downstream analysis from organ-on-a-chip sample are limited. Real-time monitoring for these chip-based models is not easy and mostly end time analysis is used. Although, one organon-a-chip model in combination with organoid technologies where primary patient-derived colonic epithelial cells was used to recapitulate mucus bilayer formation does allow real time monitoring (Sontheimer-Phelps et al., 2020). The use of chipbased models by industry has encouraged companies to improve the reproducibility and manufacture process of chips. The manufacturing and experimental cost of using the chip-based models is still quite high. The components needed for experiment are so far of disposable material which increases the cost even further. Additional challenges include sample collection from chip, which can cause change in concentrations of metabolites when samples are withdrawn during experimental run. The samples size that can be obtained from these models is small because of small numbers of cells which may be a constraint for downstream analysis. Like all in vitro models the benefits of organs-on-a-chip need to be weighed against disadvantages when designing the experiment. As more laboratories implement these models for bacterial interaction studies the protocols will start to become standardized between labs thus leading to more physiologically relevant answers.

\section{In vitro Gastrointestinal Models}

Several different models mimicking the human gastrointestinal tract and especially the colon have been developed during the last few decades. There are batch, semi-continuous and continuous models and different conditions can be applied such as fasted or fed state, as well as different disease. In contrast to the above mentioned static and dynamic biofilm models, gastrointestinal models tend to focus on planktonic microbes rather than immobilized microbes.

Batch cultures are the simplest form of an in vitro digestive model since they are usually composed of a single vessel containing the appropriate media that is inoculated with the probiotic and pathogen, and then incubated under specific temperature and atmosphere mimicking the gastrointestinal 
conditions, before analyzes are made. In addition, fecal derived bacteria can also be mixed to the batch cultures (Tejero-Sariñena et al., 2013; Piatek et al., 2020). Although this is a simple model, it is still an informative tool for larger screening.

The more advanced models have been built for different purposes. While some models mimic the whole gastrointestinal tract like, SHIME (Van de Wiele et al., 2015) others represent a specific part like colon by EnteroMix (Lamichhane et al., 2016), or combination of two different models like TIM-1 and TIM2 (Minekus, 2015). Shortly, SHIME consists of five reactors and allows culturing of the intestinal microbiota over a longer period of time and it is possible to assess probiotic properties of food or ingredients after a 2-3-week administration of the probiotic product. EnteroMix consist of four glass vessels representing the different parts of the colon. While SHIME has a feeding rate of $140 \mathrm{~mL} \mathrm{3x/day,} \mathrm{EnteroMix} \mathrm{has} \mathrm{a} \mathrm{feeding} \mathrm{rate} \mathrm{of} 24 \mathrm{ml}$ per day. TIM-1 represents the stomach to small intestine, while TIM-2 simulates the colon.

The different models apply variable setups and different types of active components and concentrations. Moreover, different fluid flows are applied, e.g., batch vs. semi-continuous vs. continuous flow. However, one thing many of these models have in common for having a representative gut microbiota, is the use of fecal samples. Currently this is the best solution, although, the fecal samples do not provide the information about in probiotic -pathogen interaction in the small intestine, where most of the digestive process are carried out.

Many of the models are built for assessing how different food components affect the gut microbiota and hence enable monitoring or quantification of microbial changes as well as microbial metabolites in different parts of the gastrointestinal tract. The models can also be used for studying antibiotic induced dysbiosis and the restoration of the gut microbiota (Liu et al., 2020).

One example of a pathogen that has been investigated with or without probiotics in more complex digestive in vitro models is $C$. difficile. Although $C$. difficile can be present in the adult commensal gut microbiota, antibiotic treatment increases the risk of infection due to $C$. difficile (Zhang et al., 2015). This organism has been studied in e.g., the EnteroMix and PolyFermS models. In the EnteroMix model the pathogen was included as vegetative cells (Forssten et al., 2015), while the PolyFermS used both vegetative cells and spores (Fehlbaum et al., 2019).

As discussed above, the effect on the gut epithelium is important and hence, the digestive models can be combined with different cell models, preferably with all the layers of the mucosa. None of the models make it possible to directly study the diseased states of the gut or interactions between the aerobic and anaerobic gut microbiota and the host intestinal epithelium that is important when studying health effects. In addition, it should be possible to culture each part without losing their characteristics, i.e., the model should include adequate oxygenation and nutrients to the cell medium, as well as physiological shear and have a biochemical environment that enables the crosstalk between epithelium, immune system and the gut microbiota (Costa and Ahluwalia, 2019; JaliliFiroozinezhad et al., 2019).

\section{In silico Models}

Since probiotics have different mechanisms of action in the gut, one possibility to investigate their interactions with gut microbiota and pathogens is by in silico approaches and this is an emerging field (Geng et al., 2021). Mathematical models have been used for, e.g., to predict the conditions under which probiotics may be successful in promoting the health of infants suffering from NEC (Arciero et al., 2010) while genome scale metabolic models (GEMs) can be used for evaluating the metabolic potential of a probiotic as well as the interaction with other organisms in the gut microbiota (Choi et al., 2020).

\section{Ex vivo Models of Functional Tissues}

Ex vivo models are made up of functional live tissues including complex cellular environments cultured outside the host. Human intestinal explant technology allows maintenance of whole organ or a part of it in culture by using specialized conditions (Randall et al., 2011; Tsilingiri et al., 2013). These tissue explants have the obvious disadvantages of difficulty in acquiring tissue samples and the short explant viability; regardless these models have been used to study interaction of microbiota with host. Thus, these methods are unsuitable for high throughput screening. Few studies have used this technology to determine the interaction of intestinal microbiota and the effect of different microbes (Randall et al., 2011; Bergström et al., 2016). Overall, ex vivo systems contain added complexity and functional crosstalk between many different cell types that are not generally found in in vitro systems (Roeselers et al., 2013). A limitation of current ex vivo systems is that they cannot be used in anaerobic environment which is a requirement for studying the intestinal niche. The field for ex vivo model is developing and given the interest, available organ types and advances in real time monitoring techniques it is likely improvements for ex vivo models will be seen.

The InTESTine model uses fresh healthy porcine intestinal tissue from gastrointestinal tract, mounted horizontally to an oxygenated incubator. The model was designed for drug discovery research and can be used with or without the microbiota incorporated and hence it can be used to study bacteria-host interaction. The model includes a mucus layer allowing better culturing of mixed bacteria community. Another ex vivo model, the Ussing chamber has been developed to utilize live mammalian tissues or cell on snap-well dishes. A drawback with Ussing chambers is that the tissue remains viable for a limited time and cannot be used for studies longer than approximately $5 \mathrm{~h}$ (Thomson et al., 2019). Ussing chambers have been used, e.g., for studying infection of Caco-2 monolayers by EIEC and the impact of a probiotic mixture (B. longum, $L$. acidophilus, and E. faecalis), or single strains, and the probiotic treatment was shown to enhance resistance to the EIEC invasion as well as reduced the secretion of proinflammatory cytokines (Shi et al., 2014).

Other examples of ex vivo tissue culture models include the calf ileal epithelium model (Frost et al., 1997) the human intestinal in vitro organ culture (IVOC) model (Haque et al., 2004). IVOC can also be used with Ussing chamber (Van Krimpen et al., 2014), the ex vivo intestinal mucosa 
model (Tsilingiri et al., 2013), and the ex vivo immature human intestinal tissue model (Newburg et al., 2016). These models mimic the organs during infection. However, the ex vivo models have their own challenges such as their short lifespan, laborious set up, inconsistency in experiments, and limited availability of cells.

\section{"Simpler" Animal Models for Microbiota Research}

Lower vertebrates and invertebrates can also be used for studying probiotic-pathogen interactions (Newton et al., 2013; Douglas, 2019). These systems have microbiomes with lower taxonomic diversity than in mammals. For example, the nematode, Caenorhabditis elegans although a well-established model for some areas, it is still in its early stages as a model to study microbiome interactions. The use of invertebrates like the honey bee (Apis mellifera) (Zheng et al., 2018), Ciona robusta (Liberti et al., 2021), fruit flies (Drosophila melanogaster), and greater wax moth (Galleria mellonella) are also an emerging field.

There are several reasons why C. elegans can be an excellent model to replace vertebrates in research conducted on viable models. There are physiological and functional similarities between microvilli in human intestines and C. elegans and 40\% of the genes of C. elegans are homologous to humans (Lai et al., 2000). C. elegans has a short life ranging from 2 to 3 weeks which make it possible to study the effect of host-microbe on the whole lifespan. The worms are transparent which makes visualization of organs or colonization of microbes a possibility using microscopy. The C. elegans can be fed fluorescently tagged bacteria and the interaction and colonization of bacteria can be imaged in real time in the viable worm body (Rezzoagli et al., 2019). Some studies have investigated the effect of probiotics such as lactobacilli, Bacillus and bifidobacteria, on metabolism, signaling, pathogen-specific defense responses, and lifespan of C. elegans (Zanni et al., 2015; Kumar et al., 2020; Poupet et al., 2020). Also immune modulation by selected probiotic strains has successfully been investigated in C. elegans models (e.g., Kim and Mylonakis, 2012; Zhou et al., 2014; Lee et al., 2015).

Despite all the advantages of research using C. elegans, there are some important aspects that need to be considered; like, e.g., the impact of its own microbial community and the interaction of its species with its host to determine which changes should be expected when researcher manipulate its microbiota by feeding bacteria of interest. Another consideration before using the C. elegans models for microbiome studies for human research is that although $C$. elegans overlap with human profile at the phylum level, it is completely different at the genus level. While, Firmicutes and Bacteroidetes comprises a major proportion of human microbiota, Proteobacteria are the main colonizers in C. elegans (Dirksen et al., 2016; Samuel et al., 2016).

Another non-vertebrate in vivo model that can be used for host microbiota interaction studies is D. melanogaster. The fly model can be used to perform studies validating the effect of probiotics on living organisms. This model has advantages like being inexpensive and breeds rapidly as well as high throughput screening capabilities including tools for studying host-microbe interaction as it has been used as a model in pathogen research (Trinder et al., 2017; Poupet et al., 2020). A limitation of using D. melanogaster is that their intestine is physiologically quite different from mammals but the gastrointestinal physiology, anatomy and signaling are highly conserved (Apidianakis and Rahme, 2011). D. melanogaster has a lower microbial diversity than humans, with only 1-30 species and Lactobacillus sensu lato and Acetobacter are the most dominant ones (Wong et al., 2011; Chaston et al., 2014). In addition, unlike C. elegans the microbial strains cannot be fed to the $D$. melanogaster but must be injected which eliminates the initial stages of the infection process. D. melanogaster has been used to some extent for probioticpathogen studies. When live microorganisms (Bacillus cereus, Candida inconspicua, Issatchenkia hanoiensis, and Klebsiella sp., mixed in an artificial diet) were fed to D. melanogaster for 1 day prior to infection with Aspergillus flavus the mortality of the flies was significantly decreased as compared to controls infected with A. flavus alone (Ramírez-Camejo et al., 2017). Others have shown that $L$. plantarum decreased the survival rate of Diaporthe FY infected Drosophila (Su et al., 2019), as well as mitigated survival deficits after Serratia marcescens septic infection (Daisley et al., 2017).

A lesser used invertebrate model is the wax moth Galleria mellonella (Cutuli et al., 2019). This model has the limitation that there are fewer investigative techniques available for it. However, a big advantage is that it can survive at both 25 and $37^{\circ} \mathrm{C}$ which makes it a promising tool (Nathan, 2014). It has been used as a model to study bacterial pathogenesis (Ramarao et al., 2012; Mukherjee et al., 2013). In a study by Vilela et al. (2015) larvae were used as a model for pathogenic yeast infection with $C$. albicans and co-infection with a strain of $L$. acidophilus. An advantage is that unlike the previously mentioned non-vertebrate models the immune mechanisms of G. mellonella is quite similar to humans (Nathan, 2014). The genome of G. mellonella has not been completely sequenced yet and there is need to standardize the methods between different laboratories (Mukherjee et al., 2013; Nathan, 2014). Another study showed the in vitro long-term colonization of two type strains of $L$. plantarum both in vitro on colon cells lines (Caco-2 and HT-29) and in vivo in G. mellonella. This study also showed the reliability of $G$. mellonella oral administration model as a first-line screening tool for in vitro to in vivo translation (Venditti et al., 2021). Another study successfully demonstrated G. mellonella as an in vivo model to assess the protection conferred by probiotic microorganisms against gastrointestinal pathogens. The antibacterial activity of probiotic strains, L. rhamnosus GG and Clostridium butyricum Miyairi, was tested against three enteric pathogens causing infection in G. mellonella: Salmonella enterica Typhimurium, EPEC or Listeria monocytogenes (Scalfaro et al., 2017).

\section{FUTURE PERSPECTIVE}

While there are regulatory aspects for novel probiotic species (EFSA, 2020), as well as regulation (2017/746) on in vitro diagnostic medical devices (IVDR), i.e., any medical device 
which is a reagent, reagent product, calibrator, control material, kit, instrument, apparatus, piece of equipment, software or system, whether used alone or in combination, intended by the manufacturer to be used in vitro for the examination of specimens, including blood and tissue donations, derived from the human body, solely or principally for the purpose of providing information on, e.g., concerning a physiological or pathological process or state or to determine the safety and compatibility with potential recipients (Dagher et al., 2019). However, no specific regulation for non-medical in vitro methods exists.

Due to the differences between models and the difficulty to compare the results between the different models and different teams, an effort made to improve this lack was the COST INFOGEST network (Brodkorb et al., 2019; Colombo et al., 2021). The network aimed to develop a static model that is easy to set up and that could be applied for the large research community, i.e., "to harmonize in vitro static systems that simulate digestive processes by defining key parameters and conditions." Thus, by combining this static model with other dynamic models, more in vivo like conditions can be achieved, since it would be important to develop intestinal in vitro models that can be specifically used for specific research questions and to improve the translation of in vitro to in vivo research within the gastroenterology area.

\section{REFERENCES}

Altamimi, M., Abdelhay, O., and Rastall, R. A. (2016). Effect of oligosaccharides on the adhesion of gut bacteria to human HT-29 cells. Anaerobe 39, 136-142. doi: 10.1016/j.anaerobe.2016.03.010

Aoki-Yoshida, A., Saito, S., Fukiya, S., Aoki, R., Takayama, Y., Suzuki, C., et al. (2016). Lactobacillus rhamnosus GG increases Toll-like receptor 3 gene expression in murine small intestine ex vivo and in vivo. Benef Microbes 7, 421-429. doi: 10.3920/bm2015.0169

Apidianakis, Y., and Rahme, L. G. (2011). Drosophila melanogaster as a model for human intestinal infection and pathology. Dis. Model. Mech. 4, 21-30. doi: $10.1242 / \mathrm{dmm} .003970$

Arcidiacono, S., Ehrenworth Breedon, A. M., Goodson, M. S., Doherty, L. A., Lyon, W., Jimenez, G., et al. (2021). In vitro fermentation test bed for evaluation of engineered probiotics in polymicrobial communities. J. Biol. Methods 8:e147. doi: $10.14440 /$ jbm.2021.347

Arciero, J. C., Ermentrout, G. B., Upperman, J. S., Vodovotz, Y., and Rubin, J. E. (2010). Using a mathematical model to analyze the role of probiotics and inflammation in necrotizing enterocolitis. PLoS One 5:e10066. doi: 10.1371/ journal.pone.0010066

Azevedo, A. S., Almeida, C., Gomes, L. C., Ferreira, C., Mergulhão, F. J., Melo, L. F., et al. (2017). An in vitro model of catheter-associated urinary tract infections to investigate the role of uncommon bacteria on the Escherichia coli microbial consortium. Biochem. Eng. J. 118, 64-69. doi: 10.1016/j.bej.2016.11.013

Baddal, B., and Marrazzo, P. (2021). Refining host-pathogen interactions: organon-chip side of the coin. Pathogens (Basel, Switzerland) 10:203. doi: 10.3390/ pathogens 10020203

Balouiri, M., Sadiki, M., and Ibnsouda, S. K. (2016). Methods for in vitro evaluating antimicrobial activity: a review. J. Pharmaceutical Anal. 6, 71-79. doi: 10.1016/ j.jpha.2015.11.005

Barrila, J., Crabbé, A., Yang, J., Franco, K., Nydam, S. D., Forsyth, R. J., et al. (2018). Modeling host-pathogen interactions in the context of the microenvironment: three-dimensional cell culture comes of age. Infect. Immun. 86:e00282-18. doi: 10.1128/iai.00282-218

Barrila, J., Radtke, A. L., Crabbé, A., Sarker, S. F., Herbst-Kralovetz, M. M., Ott, C. M., et al. (2010). Organotypic 3D cell culture models: using the rotating

\section{CONCLUSION}

In conclusion, the main challenge with the different gastrointestinal models is to have physiologically relevant models that mimic the in vivo response. In addition, it is highly appreciated if results can be achieved precisely in as short time as possible, and that it is possible to perform analysis of supplements or foods with different composition. The ideal model includes all essential features of the biological counterpart it is intended to represent, and as all above described methods have their own advantages and limitations (Table 1), thus each model needs to be assessed before use to answer a specific research question.

\section{AUTHOR CONTRIBUTIONS}

MA: writing - original draft preparation. AO and SF: writingreview and editing. AL: review and editing. All authors have read and agreed to the published version of the manuscript.

\section{FUNDING}

This work was funded by Danisco Sweeteners Oy.

wall vessel to study host-pathogen interactions. Nat. Rev. Microbiol. 8, 791-801. doi: $10.1038 /$ nrmicro 2423

Baumann, K. (2017). Stem cells: colonic organoids for drug testing and colorectal disease modelling. Nat. Rev. Mol. Cell Biol. 18:467. doi: 10.1038/nrm.2017.70

Bédard, P., Gauvin, S., Ferland, K., Caneparo, C., Pellerin, Ė, Chabaud, S., et al. (2020). Innovative human three-dimensional tissue-engineered models as an alternative to animal testing. Bioengineering (Basel, Switzerland) 7:115. doi: 10.3390/bioengineering7030115

Bein, A., Shin, W., Jalili-Firoozinezhad, S., Park, M. H., Sontheimer-Phelps, A., Tovaglieri, A., et al. (2018). Microfluidic organ-on-a-chip models of human intestine. Cell Mol. Gastroenterol. Hepatol. 5, 659-668. doi: 10.1016/j.jcmgh. 2017.12.010

Bergström, J. H., Birchenough, G. M. H., Katona, G., Schroeder, B. O., Schütte, A., Ermund, A., et al. (2016). Gram-positive bacteria are held at a distance in the colon mucus by the lectin-like protein ZG16. Proc. Natl. Acad. Sci. U S A. 113, 13833-13838. doi: 10.1073/pnas.1611400113

Bermudez-Brito, M., Plaza-Diaz, J., Munoz-Quezada, S., Gomez-Llorente, C., and Gil, A. (2012). Probiotic mechanisms of action. Ann. Nutr. Metab. 61, 160-174. doi: $10.1159 / 000342079$

Biagini, F., Calvigioni, M., Lapomarda, A., Vecchione, A., Magliaro, C., De Maria, C., et al. (2020). A novel 3D in vitro model of the human gut microbiota. Sci. Rep. 10:21499. doi: 10.1038/s41598-020-78591-w

Bourland, J., Fradette, J., and Auger, F. A. (2018). Tissue-engineered 3D melanoma model with blood and lymphatic capillaries for drug development. Sci. Rep. 8:13191. doi: 10.1038/s41598-018-31502-31506

Braverman, J., and Yilmaz, ÖH. (2018). From 3D organoids back to 2D enteroids. Dev. Cell 44, 533-534. doi: 10.1016/j.devcel.2018.02.016

Brodkorb, A., Egger, L., Alminger, M., Alvito, P., Assunção, R., Ballance, S., et al. (2019). INFOGEST static in vitro simulation of gastrointestinal food digestion. Nat. Protoc. 14, 991-1014. doi: 10.1038/s41596-018-0119-111

Brodmann, T., Endo, A., Gueimonde, M., Vinderola, G., Kneifel, W., de Vos, W. M., et al. (2017). Safety of novel microbes for human consumption: practical examples of assessment in the European Union. Front. Microbiol. 8:1725. doi: 10.3389/fmicb.2017.01725

Ceri, H., Olson, M. E., Stremick, C., Read, R. R., Morck, D., and Buret, A. (1999). The calgary biofilm device: new technology for rapid determination of 
antibiotic susceptibilities of bacterial biofilms. J. Clin. Microbiol. 37, 1771-1776. doi: 10.1128/JCM.37.6.1771-1776.1999

Chaston, J. M., Newell, P. D., and Douglas, A. E. (2014). Metagenomewide association of microbial determinants of host phenotype in Drosophila melanogaster. mBio 5:e01631-14. doi: 10.1128/mBio.016311614

Chinwalla, A. T., Cook, L. L., Delehaunty, K. D., Fewell, G. A., Fulton, L. A., Fulton, R. S., et al. (2002). Initial sequencing and comparative analysis of the mouse genome. Nature 420, 520-562. doi: 10.1038/nature01262

Choi, Y.-M., Lee, Y. Q., Song, H.-S., and Lee, D.-Y. (2020). Genome scale metabolic models and analysis for evaluating probiotic potentials. Biochem. Soc. Trans. 48, 1309-1321. doi: 10.1042/bst20190668

Co, J. Y., Margalef-Català, M., Li, X., Mah, A. T., Kuo, C. J., Monack, D. M., et al. (2019). Controlling epithelial polarity: a human enteroid model for hostpathogen interactions. Cell Rep. 26, 2509-2520.e4. doi: 10.1016/j.celrep.2019. 01.108 .

Coenye, T., and Nelis, H. J. (2010). In vitro and in vivo model systems to study microbial biofilm formation. J. Microbiol. Methods 83, 89-105. doi: 10.1016/j. mimet.2010.08.018

Collado, M. C., Meriluoto, J., and Salminen, S. (2007). Role of commercial probiotic strains against human pathogen adhesion to intestinal mucus. Lett. Appl. Microbiol. 45, 454-460. doi: 10.1111/j.1472-765X.2007.02212.x

Colombo, R., Ferron, L., Frosi, I., and Papetti, A. (2021). Advances in static in vitro digestion models after the COST action infogest consensus protocol. Food Funct. 12, 7619-7636. doi: 10.1039/D1FO01089A

Coors, M. E., Glover, J. J., Juengst, E. T., and Sikela, J. M. (2010). The ethics of using transgenic non-human primates to study what makes us human. Nat. Rev. Genet. 11, 658-662. doi: 10.1038/nrg2864

Costa, J., and Ahluwalia, A. (2019). Advances and current challenges in intestinal in vitro model engineering: a digest. Front. Bioeng. Biotechnol. 7:144. doi: 10. 3389/fbioe.2019.00144

Cui, X., Shi, Y., Gu, S., Yan, X., Chen, H., and Ge, J. (2018). Antibacterial and antibiofilm activity of lactic acid bacteria isolated from traditional artisanal milk cheese from northeast china against enteropathogenic bacteria. Probiotics Antimicrob Proteins 10, 601-610. doi: 10.1007/s12602-017-93649369

Cutuli, M. A., Petronio Petronio, G., Vergalito, F., Magnifico, I., Pietrangelo, L., Venditti, N., et al. (2019). Galleria mellonella as a consolidated in vivo model hosts: new developments in antibacterial strategies and novel drug testing. Virulence 10, 527-541. doi: 10.1080/21505594.2019.1621649

Dagher, G., Becker, K.-F., Bonin, S., Foy, C., Gelmini, S., Kubista, M., et al. (2019). Pre-analytical processes in medical diagnostics: new regulatory requirements and standards. New Biotechnol. 52, 121-125. doi: 10.1016/j.nbt.2019.05.002

Daisley, B. A., Trinder, M., McDowell, T. W., Welle, H., Dube, J. S., Ali, S. N., et al. (2017). Neonicotinoid-induced pathogen susceptibility is mitigated by Lactobacillus plantarum immune stimulation in a Drosophila melanogaster model. Sci. Rep. 7:2703. doi: 10.1038/s41598-017-02806-w

Devriese, S., Van den Bossche, L., Van Welden, S., Holvoet, T., Pinheiro, I., Hindryckx, P., et al. (2017). T84 monolayers are superior to Caco-2 as a model system of colonocytes. Histochem. Cell Biol. 148, 85-93. doi: 10.1007/s00418017-1539-1537

Dicks, L. M., and Botes, M. (2010). Probiotic lactic acid bacteria in the gastrointestinal tract: health benefits, safety and mode of action. Benef Microbes 1, 11-29. doi: 10.3920/bm2009.0012

Dieterich, W., Schink, M., and Zopf, Y. (2018). Microbiota in the gastrointestinal tract. Med. Sci. (Basel, Switzerland) 6:116. doi: 10.3390/medsci6040116

Dirksen, P., Marsh, S. A., Braker, I., Heitland, N., Wagner, S., Nakad, R., et al. (2016). The native microbiome of the nematode Caenorhabditis elegans: gateway to a new host-microbiome model. BMC Biol. 14:38. doi: 10.1186/ s12915-016-0258-251

Douglas, A. E. (2019). Simple animal models for microbiome research. Nat. Rev. Microbiol. 17, 764-775. doi: 10.1038/s41579-019-0242-241

Dutta, D., Heo, I., and Clevers, H. (2017). Disease modeling in stem cell-derived 3D organoid systems. Trends Mol, Med. 23, 393-410. doi: 10.1016/j.molmed.2017. 02.007

Dutton, J. S., Hinman, S. S., Kim, R., Wang, Y., and Allbritton, N. L. (2019). Primary cell-derived intestinal models: recapitulating physiology. Trends Biotechnol. 37, 744-760. doi: 10.1016/j.tibtech.2018.12.001
Duval, K., Grover, H., Han, L.-H., Mou, Y., Pegoraro, A. F., Fredberg, J., et al. (2017). Modeling physiological events in 2D vs. 3D cell culture. Physiology (Bethesda, Md.) 32, 266-277. doi: 10.1152/physiol.00036.2016

Edmondson, R., Broglie, J. J., Adcock, A. F., and Yang, L. (2014). Threedimensional cell culture systems and their applications in drug discovery and cell-based biosensors. Assay Drug Dev. Technol. 12, 207-218. doi: 10.1089/adt. 2014.573

EFSA (2020). Scientific opinion on the update of the list of QPS-recommended biological agents intentionally added to food or feed as notified to EFSA (2017-2019). EFSA J. 18:e05966. doi: 10.2903/j.efsa.2020.5966

Ettayebi, K., Crawford, S. E., Murakami, K., Broughman, J. R., Karandikar, U. Tenge, V. R., et al. (2016). Replication of human noroviruses in stem cellderived human enteroids. Science (New York, N.Y.) 353, 1387-1393. doi: 10. $1126 /$ science.aaf5211

Fehlbaum, S., Chassard, C., Schwab, C., Voolaid, M., Fourmestraux, C., Derrien, M., et al. (2019). In vitro study of Lactobacillus paracasei CNCM I-1518 in healthy and clostridioides difficile colonized elderly gut microbiota. Front. Nutr. 6:184. doi: $10.3389 /$ fnut.2019.00184

Fijan, S. (2014). Microorganisms with claimed probiotic properties: an overview of recent literature. Int. J. Environ. Res. Public Health 11, 4745-4767. doi: 10.3390/ijerph110504745

Fijan, S. (2016). "Antimicrobial effect of probiotics against common pathogens," in Probiotics and Prebiotics in Human Nutrition and Health, eds V. Rao and L. G. Rao (London: IntechOpen).

Finlay, B. B., and Brumell, J. H. (2000). Salmonella interactions with host cells: in vitro to in vivo. Philos. Trans. R. Soc. Lond. B Biol. Sci. 355, 623-631. doi: $10.1098 /$ rstb.2000.0603

Flemming, H.-C., Wingender, J., Szewzyk, U., Steinberg, P., Rice, S. A., and Kjelleberg, S. (2016). Biofilms: an emergent form of bacterial life. Nat. Rev. Microbiol. 14, 563-575. doi: 10.1038/nrmicro.2016.94

Forbester, J. L., Goulding, D., Vallier, L., Hannan, N., Hale, C., Pickard, D., et al. (2015). Interaction of Salmonella enterica serovar typhimurium with intestinal organoids derived from human induced pluripotent stem cells. Infect. Immun. 83, 2926-2934. doi: 10.1128/IAI.00161-115

Forssten, S. D., Röytiö, H., Hibberd, A. A., and Ouwehand, A. C. (2015). The effect of polydextrose and probiotic lactobacilli in a Clostridium difficile-infected human colonic model. Microbial Ecol. Health Dis. 26, 27988-27988. doi: 10. 3402/mehd.v26.27988

Foulke-Abel, J., In, J., Kovbasnjuk, O., Zachos, N. C., Ettayebi, K., Blutt, S. E., et al. (2014). Human enteroids as an ex-vivo model of host-pathogen interactions in the gastrointestinal tract. Exp. Biol. Med. (Maywood) 239, 1124-1134. doi: $10.1177 / 1535370214529398$

Freire, R., Ingano, L., Serena, G., Cetinbas, M., Anselmo, A., Sapone, A., et al. (2019). Human gut derived-organoids provide model to study gluten response and effects of microbiota-derived molecules in celiac disease. Sci. Rep. 9:7029. doi: 10.1038/s41598-019-43426-w

Frost, J. A., Steen, H., Shapiro, P., Lewis, T., Ahn, N., Shaw, P. E., et al. (1997). Cross-cascade activation of ERKs and ternary complex factors by Rho family proteins. EMBO J. 16, 6426-6438. doi: 10.1093/emboj/16.21.6426

Gabrilska, R. A., and Rumbaugh, K. P. (2015). Biofilm models of polymicrobial infection. Future Microbiol. 10, 1997-2015. doi: 10.2217/fmb.15.109

Gagnon, M., Zihler Berner, A., Chervet, N., Chassard, C., and Lacroix, C. (2013). Comparison of the Caco-2, HT-29 and the mucus-secreting HT29MTX intestinal cell models to investigate Salmonella adhesion and invasion. J. Microbiol. Methods 94, 274-279. doi: 10.1016/j.mimet.2013.06.027

Geng, J., Ji, B., Li, G., López-Isunza, F., and Nielsen, J. (2021). CODY enables quantitatively spatiotemporal predictions on in vivo gut microbial variability induced by diet intervention. Proc. Natl. Acad. Sci. U S A. 118:e2019336118. doi: $10.1073 /$ pnas. 2019336118

Gharbi, Y., Fhoula, I., Ruas-Madiedo, P., Afef, N., Boudabous, A., Gueimonde, M., et al. (2019). In-vitro characterization of potentially probiotic Lactobacillus strains isolated from human microbiota: interaction with pathogenic bacteria and the enteric cell line HT29. Ann. Microbiol. 69, 61-72. doi: 10.1007/s13213018-1396-1

Gomez, N. C., Ramiro, J. M., Quecan, B. X., and de Melo Franco, B. D. (2016). Use of potential probiotic Lactic Acid Bacteria (LAB) biofilms for the control of Listeria monocytogenes, Salmonella Typhimurium, and Escherichia coli O157:H7 biofilms formation. Front. Microbiol. 7:863. doi: 10.3389/fmicb.2016.00863 
Gonzalez, L. M., Williamson, I., Piedrahita, J. A., Blikslager, A. T., and Magness, S. T. (2013). Cell lineage identification and stem cell culture in a porcine model for the study of intestinal epithelial regeneration. PLoS One 8:e66465. doi: 10.1371/journal.pone.0066465

Guan, C., Chen, X., Jiang, X., Zhao, R., Yuan, Y., Chen, D., et al. (2020). In vitro studies of adhesion properties of six lactic acid bacteria isolated from the longevous population of China. RSC Adv. 10, 24234-24240. doi: 10.1039/ D0RA03517C

Guantario, B., Zinno, P., Schifano, E., Roselli, M., Perozzi, G., Palleschi, C., et al. (2018). In vitro and in vivo selection of potentially probiotic Lactobacilli from nocellara del belice table olives. Front. Microbiol. 9:595. doi: 10.3389/fmicb. 2018.00595

Hager, C. L., Isham, N., Schrom, K. P., Chandra, J., McCormick, T., Miyagi, M., et al. (2019). Effects of a novel probiotic combination on pathogenic bacterialfungal polymicrobial biofilms. mBio 10:e0338-19. doi: 10.1128/mBio.00338319

Han, X., Lee, A., Huang, S., Gao, J., Spence, J. R., and Owyang, C. (2019). Lactobacillus rhamnosus GG prevents epithelial barrier dysfunction induced by interferon-gamma and fecal supernatants from irritable bowel syndrome patients in human intestinal enteroids and colonoids. Gut Microbes 10, 59-76. doi: 10.1080/19490976.2018.1479625

Haque, A., Bowe, F., Fitzhenry, R. J., Frankel, G., Thomson, M., Heuschkel, R., et al. (2004). Early interactions of Salmonella enterica serovar typhimurium with human small intestinal epithelial explants. Gut 53, 1424-1430. doi: 10. 1136/gut.2003.037382

Heinritz, S. N., Mosenthin, R., and Weiss, E. (2013). Use of pigs as a potential model for research into dietary modulation of the human gut microbiota. Nutrit. Res. Rev. 26, 191-209. doi: 10.1017/S0954422413000152

Heo, I., Dutta, D., Schaefer, D. A., Iakobachvili, N., Artegiani, B., Sachs, N., et al. (2018). Modelling Cryptosporidium infection in human small intestinal and lung organoids. Nat. Microbiol. 3, 814-823. doi: 10.1038/s41564-018-0177-178

Hill, C., Guarner, F., Reid, G., Gibson, G. R., Merenstein, D. J., Pot, B., et al. (2014). Expert consensus document. the international scientific association for probiotics and Prebiotics consensus statement on the scope and appropriate use of the term probiotic. Nat. Rev. Gastroenterol. Hepatol. 11, 506-514. doi: $10.1038 /$ nrgastro. 2014.66

Hill, D. R., Huang, S., Nagy, M. S., Yadagiri, V. K., Fields, C., Mukherjee, D., et al. (2017). Bacterial colonization stimulates a complex physiological response in the immature human intestinal epithelium. eLife 6:e29132. doi: 10.7554/eLife. 29132

Hoarau-Véchot, J., Rafii, A., Touboul, C., and Pasquier, J. (2018). Halfway between $2 \mathrm{D}$ and animal models: are $3 \mathrm{D}$ cultures the ideal tool to study cancer-microenvironment interactions? Int. J. Mol. Sci. 19:181. doi: 10.3390/ ijms19010181

Hou, Q., Ye, L., Liu, H., Huang, L., Yang, Q., Turner, J. R., et al. (2018). Lactobacillus accelerates ISCs regeneration to protect the integrity of intestinal mucosa through activation of STAT3 signaling pathway induced by LPLs secretion of IL-22. Cell Death. Differ. 25, 1657-1670. doi: 10.1038/s41418-018-0070-72

Hussey, G. S., Keane, T. J., and Badylak, S. F. (2017). The extracellular matrix of the gastrointestinal tract: a regenerative medicine platform. Nat. Rev. Gastroenterol. Hepatol. 14, 540-552. doi: 10.1038/nrgastro.2017.76

In, J., Foulke-Abel, J., Zachos, N. C., Hansen, A. M., Kaper, J. B., Bernstein, H. D., et al. (2016). Enterohemorrhagic Escherichia coli reduce mucus and intermicrovillar bridges in human stem cell-derived colonoids. Cell Mol. Gastroenterol. Hepatol. 2, 48-62.e3. doi: 10.1016/j.jcmgh.2015.10.001.

Ingber, D. E. (2016). Reverse engineering human pathophysiology with organs-onchips. Cell 164, 1105-1109. doi: 10.1016/j.cell.2016.02.049

Jalili-Firoozinezhad, S., Gazzaniga, F. S., Calamari, E. L., Camacho, D. M., Fadel, C. W., Bein, A., et al. (2019). A complex human gut microbiome cultured in an anaerobic intestine-on-a-chip. Nat. Biomed. Eng. 3, 520-531. doi: 10.1038/ s41551-019-0397-390

Jiminez, J. A., Uwiera, T. C., Douglas Inglis, G., and Uwiera, R. R. (2015). Animal models to study acute and chronic intestinal inflammation in mammals. Gut Pathog 7:29. doi: 10.1186/s13099-015-0076-y

Jose, N. M., Bunt, C. R., McDowell, A., Chiu, J. Z. S., and Hussain, M. A. (2017). Short communication: a study of Lactobacillus isolates' adherence to and influence on membrane integrity of human Caco-2 cells. J. Dairy Sci. 100, 7891-7896. doi: 10.3168/jds.2017-12912
Joshi, P., Kang, S. Y., Datar, A., and Lee, M. Y. (2019). High-Throughput assessment of mechanistic toxicity of chemicals in miniaturized 3D cell culture. Curr. Protoc. Toxicol. 79:e66. doi: 10.1002/cptx.66

Kar, S. K., Wells, J. M., Ellen, E. D., te Pas, M. F. W., Madsen, O., Groenen, M. A. M., et al. (2021). Organoids: a promising new in vitro platform in livestock and veterinary research. Vet. Res. 52:43. doi: 10.1186/s13567-021-00904-902

Karve, S. S., Pradhan, S., Ward, D. V., and Weiss, A. A. (2017). Intestinal organoids model human responses to infection by commensal and Shiga toxin producing Escherichia coli. PLoS One 12:e0178966. doi: 10.1371/journal.pone.0178966

Kasendra, M., Tovaglieri, A., Sontheimer-Phelps, A., Jalili-Firoozinezhad, S., Bein, A., Chalkiadaki, A., et al. (2018). Development of a primary human small intestine-on-a-chip using biopsy-derived organoids. Sci. Rep. 8:2871. doi: 10. 1038/s41598-018-21201-21207

Kaur, S., Sharma, P., Kalia, N., Singh, J., and Kaur, S. (2018). Anti-biofilm properties of the fecal probiotic Lactobacilli against Vibrio spp. Front. Cell. Infect. Microbiol. 8:120. doi: 10.3389/fcimb.2018.00120

Khailova, L., Patrick, S. K. M., Arganbright, K. M., Halpern, M. D., Kinouchi, T., and Dvorak, B. (2010). Bifidobacterium bifidum reduces apoptosis in the intestinal epithelium in necrotizing enterocolitis. Am. J. PhysiologyGastrointestinal Liver Physiol. 299, G1118-G1127. doi: 10.1152/ajpgi.00131. 2010

Khodaii, Z., Ghaderian, S. M. H., and Natanzi, M. M. (2017). Probiotic bacteria and their supernatants protect enterocyte cell lines from enteroinvasive Escherichia coli (EIEC) invasion. Int. J. Mol. Cell. Med. 6, 183-189. doi: 10.22088/acadpub. BUMS.6.3.183

Kim, H. J., and Ingber, D. E. (2013). Gut-on-a-Chip microenvironment induces human intestinal cells to undergo villus differentiation. Integr. Biol. (Camb) 5 , 1130-1140. doi: 10.1039/c3ib40126j

Kim, H. J., Huh, D., Hamilton, G., and Ingber, D. E. (2012). Human gut-on-a-chip inhabited by microbial flora that experiences intestinal peristalsis-like motions and flow. Lab Chip 12, 2165-2174. doi: 10.1039/C2LC40074J

Kim, H. J., Lee, J., Choi, J. H., Bahinski, A., and Ingber, D. E. (2016a). Coculture of living microbiome with microengineered human intestinal villi in a gut-on-a-chip microfluidic device. J. Vis. Exp. 54344. doi: 10.3791/54344

Kim, H. J., Li, H., Collins, J. J., and Ingber, D. E. (2016b). Contributions of microbiome and mechanical deformation to intestinal bacterial overgrowth and inflammation in a human gut-on-a-chip. Proc. Natl. Acad. Sci. U S A. 113, E7-E15. doi: 10.1073/pnas.1522193112

Kim, J., Hegde, M., and Jayaraman, A. (2010). Co-culture of epithelial cells and bacteria for investigating host-pathogen interactions. Lab Chip 10, 43-50. doi: 10.1039/B911367C

Kim, Y., and Mylonakis, E. (2012). Caenorhabditis elegans immune conditioning with the probiotic bacterium Lactobacillus acidophilus strain NCFM enhances gram-positive immune responses. Infect. Immun. 80, 2500-2508. doi: 10.1128/ IAI.06350-6311

Kos, B., Susković, J., Vuković, S., Simpraga, M., Frece, J., and Matosić, S. (2003). Adhesion and aggregation ability of probiotic strain Lactobacillus acidophilus M92. J. Appl. Microbiol. 94, 981-987. doi: 10.1046/j.1365-2672.2003.01915.x

Krych, L., Hansen, C. H. F., Hansen, A. K., van den Berg, F. W. J., and Nielsen, D. S. (2013). Quantitatively different, yet qualitatively alike: a meta-analysis of the mouse core gut microbiome with a view towards the human gut microbiome. PLoS One 8:e62578. doi: 10.1371/journal.pone.0062578

Kumar, A., Baruah, A., Tomioka, M., Iino, Y., Kalita, M. C., and Khan, M. (2020). Caenorhabditis elegans: a model to understand host-microbe interactions. Cell Mol. Life. Sci. 77, 1229-1249. doi: 10.1007/s00018-019-03319-3317

Lagrafeuille, R., Miquel, S., Balestrino, D., Vareille-Delarbre, M., Chain, F., Langella, P., et al. (2018). Opposing effect of Lactobacillus on in vitro Klebsiella pneumoniae in biofilm and in an in vivo intestinal colonisation model. Benef. Microbes 9, 87-100. doi: 10.3920/bm2017.0002

Lai, C. H., Chou, C. Y., Ch'ang, L. Y., Liu, C. S., and Lin, W. (2000). Identification of novel human genes evolutionarily conserved in Caenorhabditis elegans by comparative proteomics. Genome Res. 10, 703-713. doi: 10.1101/gr.10.5.703

Lamichhane, S., Westerhuis, J. A., Ouwehand, A. C., Saarinen, M. T., Forssten, S. D., Jensen, H. M., et al. (2016). Gut microbial activity as influenced by fiber digestion: dynamic metabolomics in an in vitro colon simulator. Metabolomics 12:25. doi: 10.1007/s11306-015-0936-y

Larsen, N., Michaelsen, K. F., Pærregaard, A., Vogensen, F. K., and Jakobsen, M. (2009). A comparative study on adhesion and recovery of potential 
probiotic strains of Lactobacillus spp. by in vitro assay and analysis of human colon biopsies. Microbial Ecol. Health Dis. 21, 95-99. doi: 10.1080/ 08910600902907632

Lebeaux, D., Chauhan, A., Rendueles, O., and Beloin, C. (2013). From in vitro to in vivo models of bacterial biofilm-related infections. Pathogens 2, 288-356. doi: 10.3390/pathogens 2020288

Lee, J., Choe, J., Kim, J., Oh, S., Park, S., Kim, S., et al. (2015). Heat-killed Lactobacillus spp. cells enhance survivals of Caenorhabditis elegans against Salmonella and Yersinia infections. Lett. Appl. Microbiol. 61, 523-530. doi: 10.1111/lam.12478

Lee, J.-E., Lee, J., Kim, J. H., Cho, N., Lee, S. H., Park, S. B., et al. (2019). Characterization of the anti-cancer activity of the probiotic bacterium Lactobacillus fermentum using $2 \mathrm{D}$ vs. 3D culture in Colorectal Cancer cells. Biomolecules 9:557. doi: 10.3390/biom9100557

Leslie, J. L., Huang, S., Opp, J. S., Nagy, M. S., Kobayashi, M., Young, V. B., et al. (2015). Persistence and toxin production by Clostridium difficile within human intestinal organoids result in disruption of epithelial paracellular barrier function. Infect. Immun. 83, 138-145. doi: 10.1128/iai.025612514

Liberti, A., Natarajan, O., Atkinson, C. G. F., Sordino, P., and Dishaw, L. J. (2021). Reflections on the use of an invertebrate chordate model system for studies of gut microbial immune interactions. Front. Immunol. 12:642687. doi: 10.3389/ fimmu.2021.642687

Littman, D. R., and Pamer, E. G. (2011). Role of the commensal microbiota in normal and pathogenic host immune responses. Cell Host Microbe 10, 311-323. doi: 10.1016/j.chom.2011.10.004

Liu, L., Wang, Q., Wu, X., Qi, H., Das, R., Lin, H., et al. (2020). Vancomycin exposure caused opportunistic pathogens bloom in intestinal microbiome by simulator of the human intestinal microbial ecosystem (SHIME). Environ. Pollut. 265(Pt B):114399. doi: 10.1016/j.envpol.2020.114399

Liu, Y., Fatheree, N. Y., Mangalat, N., and Rhoads, J. M. (2010). Humanderived probiotic Lactobacillus reuteri strains differentially reduce intestinal inflammation. Am. J. Physiol. Gastrointest. Liver Physiol. 299, G1087-G1096. doi: 10.1152/ajpgi.00124.2010

Lukovac, S., Belzer, C., Pellis, L., Keijser, B. J., de Vos, W. M., Montijn, R. C., et al. (2014). Differential modulation by Akkermansia muciniphila and Faecalibacterium prausnitzii of host peripheral lipid metabolism and histone acetylation in mouse gut organoids. mBio 5:e01438-14. doi: 10.1128/mBio. 01438-1414

McGuckin, M. A., Lindén, S. K., Sutton, P., and Florin, T. H. (2011). Mucin dynamics and enteric pathogens. Nat. Rev. Microbiol. 9, 265-278. doi: 10.1038/ nrmicro2538

Meng, J., Zhang, Q. X., and Lu, R. R. (2017). Surface layer protein from Lactobacillus acidophilus NCFM inhibit intestinal pathogen-induced apoptosis in HT-29 cells. Int. J. Biol. Macromol. 96, 766-774. doi: 10.1016/j.ijbiomac.2016. 12.085

Minekus, M. (2015). “The TNO Gastro-Intestinal Model (TIM)”, in The Impact of Food Bioactives on Health: in Vitro and Ex Vivo Models, eds K. Verhoeckx, P. Cotter, I. López-Expósito, C. Kleiveland, T. Lea, A. Mackie, et al. (Cham: Springer International Publishing), 37-46. doi: 10.1007/978-3-319-16104-4_5

Mitchell, D. M., and Ball, J. M. (2004). Characterization of a spontaneously polarizing HT-29 cell line, HT-29/cl.f8. Vitro Cell Dev. Biol. Anim. 40, 297-302. doi: 10.1290/04100061.1

Montalto, M., D’Onofrio, F., Gallo, A., Cazzato, A., and Gasbarrini, G. (2009). Intestinal microbiota and its functions. Digestive Liver Dis. Suppl. 3, 30-34. doi: 10.1016/S1594-5804(09)60016-60014

Motta, J. P., Wallace, J. L., Buret, A. G., Deraison, C., and Vergnolle, N. (2021). Gastrointestinal biofilms in health and disease. Nat. Rev. Gastroenterol. Hepatol. 18, 314-334. doi: 10.1038/s41575-020-00397-y

Mukherjee, K., Hain, T., Fischer, R., Chakraborty, T., and Vilcinskas, A. (2013). Brain infection and activation of neuronal repair mechanisms by the human pathogen Listeria monocytogenes in the lepidopteran model host Galleria mellonella. Virulence 4, 324-332. doi: 10.4161/viru.23629

Nathan, S. (2014). New to Galleria mellonella: modeling an ExPEC infection. Virulence 5, 371-374. doi: 10.4161/viru.28338

Newburg, D. S., Ko, J. S., Leone, S., and Nanthakumar, N. N. (2016). Human milk oligosaccharides and synthetic galactosyloligosaccharides contain 3'-, 4-, and 6'-Galactosyllactose and attenuate inflammation in human T84, NCM-460, and
H4 cells and intestinal tissue ex vivo. J. Nutr. 146, 358-367. doi: 10.3945/jn.115. 220749

Newton, I. G., Sheehan, K., Lee, F. J., Horton, M. A., and Hicks, R. D. (2013). Invertebrate systems for hypothesis-driven microbiome research. Microbiome Sci. Med. 1, 1-9. doi: 10.2478/micsm-2013-0001

Nguyen, D.-Q., and Xu, T. (2008). The expanding role of mouse genetics for understanding human biology and disease. Dis. Models Mechan. 1, 56-66. doi: $10.1242 / \mathrm{dmm} .000232$

Ojetti, V., Gigante, G., Ainora, M. E., Fiore, F., Barbaro, F., and Gasbarrini, A. (2009). Microflora imbalance and gastrointestinal diseases. Digestive Liver Dis. Suppl. 3, 35-39. doi: 10.1016/s1594-5804(09)60017-6

Orsi, C. F., Sabia, C., Ardizzoni, A., Colombari, B., Neglia, R. G., Peppoloni, S., et al. (2014). Inhibitory effects of different lactobacilli on Candida albicans hyphal formation and biofilm development. J. Biol. Regul. Homeost. Agents 28, 743-752.

Pan, F., Han, L., Zhang, Y., Yu, Y., and Liu, J. (2015). Optimization of Caco-2 and HT29 co-culture in vitro cell models for permeability studies. Int. J. Food Sci. Nutr. 66, 680-685. doi: 10.3109/09637486.2015.1077792

Parente, E., Brienza, C., Moles, M., and Ricciardi, A. (1995). A comparison of methods for the measurement of bacteriocin activity. J. Microbiol. Methods 22, 95-108. doi: 10.1016/0167-7012(94)00068-i

Park, J. C., and Im, S.-H. (2020). Of men in mice: the development and application of a humanized gnotobiotic mouse model for microbiome therapeutics. Exp. Mol. Med. 52, 1383-1396. doi: 10.1038/s12276-020-0473-472

Patterson, J. K., Lei, X. G., and Miller, D. D. (2008). The pig as an experimental model for elucidating the mechanisms governing dietary influence on mineral absorption. Exp. Biol. Med. (Maywood) 233, 651-664. doi: 10.3181/0709-mr262

Pearce, S. C., Al-Jawadi, A., Kishida, K., Yu, S., Hu, M., Fritzky, L. F., et al. (2018). Marked differences in tight junction composition and macromolecular permeability among different intestinal cell types. BMC Biol. 16:19. doi: 10.1186/ s12915-018-0481-z

Pereira, M. G., de Almeida, O. G. G., da Silva, H. R. A., Ishizawa, M. H., and De Martinis, E. C. P. (2021). Studies on host-foodborne bacteria in intestinal threedimensional cell culture model indicate possible mechanisms of interaction. World J. Microbiol. Biotechnol. 37:31. doi: 10.1007/s11274-021-02996-2996

Perez-Ibarreche, M., Castellano, P., Leclercq, A., and Vignolo, G. (2016). Control of Listeria monocytogenes biofilms on industrial surfaces by the bacteriocinproducing Lactobacillus sakei CRL1862. FEMS Microbiol. Lett. 363:fnw118. doi: $10.1093 /$ femsle/fnw118

Piatek, J., Krauss, H., Ciechelska-Rybarczyk, A., Bernatek, M., Wojtyla-Buciora, P., and Sommermeyer, H. (2020). In-Vitro growth inhibition of bacterial pathogens by probiotics and a synbiotic: product composition matters. Int. J. Environ. Res. Public Health 17:3332. doi: 10.3390/ijerph17093332

Plaza-Diaz, J., Ruiz-Ojeda, F. J., Gil-Campos, M., and Gil, A. (2019). Mechanisms of action of probiotics. Adv. Nutrition 10(Suppl._1), S49-S66. doi: 10.1093/ advances/nmy063

Poceviciute, R., and Ismagilov, R. F. (2019). Human-gut-microbiome on a chip. Nat. Biomed. Eng. 3, 500-501. doi: 10.1038/s41551-019-0425-420

Poupet, C., Chassard, C., Nivoliez, A., and Bornes, S. (2020). Caenorhabditis elegans, a host to investigate the probiotic properties of beneficial microorganisms. Front. Nutr. 7:135. doi: 10.3389/fnut.2020.00135

Prabhurajeshwar, C., and Chandrakanth, K. (2019). Evaluation of antimicrobial properties and their substances against pathogenic bacteria in-vitro by probiotic Lactobacilli strains isolated from commercial yoghurt. Clin. Nutrition Exp. 23, 97-115. doi: 10.1016/j.yclnex.2018.10.001

Preidis, G. A., Hill, C., Guerrant, R. L., Ramakrishna, B. S., Tannock, G. W., and Versalovic, J. (2011). Probiotics, enteric and diarrheal diseases, and global health. Gastroenterology 140, 8-14. doi: 10.1053/j.gastro.2010.11.010

Rajan, A., Robertson, M. J., Carter, H. E., Poole, N. M., Clark, J. R., Green, S. I., et al. (2020). Enteroaggregative E. coli adherence to human heparan sulfate proteoglycans drives segment and host specific responses to infection. PLoS Pathogens 16:e1008851. doi: 10.1371/journal.ppat.1008851

Ramarao, N., Nielsen-Leroux, C., and Lereclus, D. (2012). The insect Galleria mellonella as a powerful infection model to investigate bacterial pathogenesis. J. Visual. Exp. JoVE e4392. doi: 10.3791/4392

Ramiah, K., van Reenen, C. A., and Dicks, L. M. (2008). Surface-bound proteins of Lactobacillus plantarum 423 that contribute to adhesion of Caco- 2 cells and 
their role in competitive exclusion and displacement of Clostridium sporogenes and Enterococcus faecalis. Res. Microbiol. 159, 470-475. doi: 10.1016/j.resmic. 2008.06.002

Ramírez-Camejo, L., García-Alicea, M., Maldonado-Morales, G., and Bayman, P. (2017). Probiotics may protect Drosophila from infection by Aspergillus flavus. Int. J. Pharm. Sci. Res. 8, 1624-1632. doi: 10.13040/IJPSR.0975-8232.8(4).16241632

Randall, K. J., Turton, J., and Foster, J. R. (2011). Explant culture of gastrointestinal tissue: a review of methods and applications. Cell Biol. Toxicol. 27, 267-284. doi: 10.1007/s10565-011-9187-9185

Resta-Lenert, S., and Barrett, K. E. (2003). Live probiotics protect intestinal epithelial cells from the effects of infection with enteroinvasive Escherichia coli (EIEC). Gut 52, 988-997. doi: 10.1136/gut.52.7.988

Rezzoagli, C., Granato, E. T., and Kummerli, R. (2019). In-vivo microscopy reveals the impact of Pseudomonas aeruginosa social interactions on host colonization. ISME J. 13, 2403-2414. doi: 10.1038/s41396-019-0442-8

Ringuette Goulet, C., Bernard, G., Chabaud, S., Couture, A., Langlois, A., Neveu, B., et al. (2017). Tissue-engineered human 3D model of bladder cancer for invasion study and drug discovery. Biomaterials 145, 233-241. doi: 10.1016/j. biomaterials.2017.08.041

Roeselers, G., Ponomarenko, M., Lukovac, S., and Wortelboer, H. M. (2013). Ex vivo systems to study host-microbiota interactions in the gastrointestinal tract. Best Pract. Res. Clin. Gastroenterol. 27, 101-113. doi: 10.1016/j.bpg.2013. 03.018

Rouanet, A., Bolca, S., Bru, A., Claes, I., Cvejic, H., Girgis, H., et al. (2020). Live biotherapeutic products, a road map for safety assessment. Front. Med. (Lausanne) 7:237. doi: 10.3389/fmed.2020.00237

Rubert, J., Schweiger, P. J., Mattivi, F., Tuohy, K., Jensen, K. B., and Lunardi, A. (2020). Intestinal organoids: a tool for modelling diet-microbiome-host interactions. Trends Endocrinol. Metab. 31, 848-858. doi: 10.1016/j.tem.2020. 02.004

Salli, K. M., Gürsoy, U. K., Söderling, E. M., and Ouwehand, A. C. (2017). Effects of xylitol and sucrose mint products on Streptococcus mutans colonization in a dental simulator model. Curr. Microbiol. 74, 1153-1159. doi: 10.1007/s00284017-1299-1296

Samuel, B. S., Rowedder, H., Braendle, C., Felix, M. A., and Ruvkun, G. (2016). Caenorhabditis elegans responses to bacteria from its natural habitats. Proc. Natl. Acad. Sci. U S A. 113, E3941-E3949. doi: 10.1073/pnas.160718 3113

Santbergen, M. J. C., van der Zande, M., Gerssen, A., Bouwmeester, H., and Nielen, M. W. F. (2020). Dynamic in vitro intestinal barrier model coupled to chipbased liquid chromatography mass spectrometry for oral bioavailability studies. Anal. Bioanal. Chem. 412, 1111-1122. doi: 10.1007/s00216-019-02336-2336

Sasaki, N., Miyamoto, K., Maslowski, K. M., Ohno, H., Kanai, T., and Sato, T. (2020). Development of a scalable coculture system for gut anaerobes and human colon epithelium. Gastroenterology 159, 388-390.e5. doi: 10.1053/j. gastro.2020.03.021.

Sato, T., and Clevers, H. (2013). Growing self-organizing mini-guts from a single intestinal stem cell: mechanism and applications. Science 340, 1190-1194. doi: $10.1126 /$ science. 1234852

Scalfaro, C., Iacobino, A., Nardis, C., and Franciosa, G. (2017). Galleria mellonella as an in vivo model for assessing the protective activity of probiotics against gastrointestinal bacterial pathogens. FEMS Microbiol. Lett. 364:fnx064. doi: 10. 1093/femsle/fnx064

Schoultz, I., and Keita, $̊ V$. (2020). The intestinal barrier and current techniques for the assessment of gut permeability. Cells 9:1909. doi: 10.3390/cells9081909

Sciascia, Q., Daş, G., and Metges, C. C. (2016). Review: the pig as a model for humans: effects of nutritional factors on intestinal function and health1. J. Anim. Sci. 94(Suppl._3), 441-452. doi: 10.2527/jas.20159788

Sebrell, T. A., Hashimi, M., Sidar, B., Wilkinson, R. A., Kirpotina, L., Quinn, M. T., et al. (2019). A novel gastric spheroid co-culture model reveals chemokinedependent recruitment of human dendritic cells to the gastric epithelium. Cell. Mol. Gastroenterol. Hepatol. 8, 157-171.e3. doi: 10.1016/j.jcmgh.2019.02.010.

Seok, J., Warren, H. S., Cuenca, A. G., Mindrinos, M. N., Baker, H. V., Xu, W., et al. (2013). Genomic responses in mouse models poorly mimic human inflammatory diseases. Proc. Natl. Acad. Sci. U S A. 110, 3507-3512. doi: 10. 1073/pnas.1222878110
Shah, P., Fritz, J. V., Glaab, E., Desai, M. S., Greenhalgh, K., Frachet, A., et al. (2016). A microfluidics-based in vitro model of the gastrointestinal human-microbe interface. Nat. Commun. 7:11535. doi: 10.1038/ncomms11535

Shamir, E. R., and Ewald, A. J. (2014). Three-dimensional organotypic culture: experimental models of mammalian biology and disease. Nat. Rev. Mol. Cell Biol. 15, 647-664. doi: 10.1038/nrm3873

Sherman, P. M., Johnson-Henry, K. C., Yeung, H. P., Ngo, P. S. C., Goulet, J., and Tompkins, T. A. (2005). Probiotics reduce enterohemorrhagic Escherichia coli O157:H7 - and enteropathogenic E. coli O127:H6-Induced changes in polarized T84 epithelial cell monolayers by reducing bacterial adhesion and cytoskeletal rearrangements. Infect. Immun. 73, 5183-5188. doi: 10.1128/IAI.73.8.51835188.2005

Shi, C.-Z., Chen, H.-Q., Liang, Y., Xia, Y., Yang, Y.-Z., Yang, J., et al. (2014). Combined probiotic bacteria promotes intestinal epithelial barrier function in interleukin-10-gene-deficient mice. World J. Gastroenterol. 20, 4636-4647. doi: 10.3748 /wjg.v20.i16.4636

Shin, W., Wu, A., Massidda, M. W., Foster, C., Thomas, N., Lee, D.-W., et al. (2019). A robust longitudinal co-culture of obligate anaerobic gut microbiome with human intestinal epithelium in an anoxic-oxic interface-on-a-chip. Front. Bioeng. Biotechnol. 7:13. doi: 10.3389/fbioe.2019.00013

Silva, D. R., Sardi, J. D. C. O., Pitangui, N. D. S., Roque, S. M., Silva, A. C. B. D., and Rosalen, P. L. (2020). Probiotics as an alternative antimicrobial therapy: current reality and future directions. J. Funct. Foods 73:104080. doi: 10.1016/j.jff.2020. 104080

Sontheimer-Phelps, A., Chou, D. B., Tovaglieri, A., Ferrante, T. B., Duckworth, T., Fadel, C., et al. (2020). Human colon-on-a-chip enables continuous in vitro analysis of colon mucus layer accumulation and physiology. Cell. Mol. Gastroenterol. Hepatol. 9, 507-526. doi: 10.1016/j.jcmgh.2019.11.008

Spence, J. R., Mayhew, C. N., Rankin, S. A., Kuhar, M. F., Vallance, J. E., Tolle, K., et al. (2011). Directed differentiation of human pluripotent stem cells into intestinal tissue in vitro. Nature 470, 105-109. doi: 10.1038/nature09691

Stelzner, M., Helmrath, M., Dunn, J. C. Y., Henning, S. J., Houchen, C. W., Kuo, C., et al. (2012). A nomenclature for intestinal in vitro cultures. Am. J. Physiol. Gastrointest. Liver Physiol. 302, G1359-G1363. doi: 10.1152/ajpgi.00493.2011

Su, W., Liu, J., Bai, P., Ma, B., and Liu, W. (2019). Pathogenic fungi-induced susceptibility is mitigated by mutual Lactobacillus plantarum in the Drosophila melanogaster model. BMC Microbiol. 19:302. doi: 10.1186/s12866-019-16861681

Sun, L., Cao, X., Lechuga, S., Feygin, A., Naydenov, N. G., and Ivanov, A. I. (2019). A septin cytoskeleton-targeting small molecule, forchlorfenuron, inhibits epithelial migration via septin-independent perturbation of cellular signaling. Cells 9:84. doi: 10.3390/cells9010084

Tannenbaum, J., and Bennett, B. T. (2015). Russell and Burch's 3Rs then and now: the need for clarity in definition and purpose. J. Am. Assoc. Lab. Animal Sci.: JAALAS 54, 120-132.

Tejero-Sariñena, S., Barlow, J., Costabile, A., Gibson, G. R., and Rowland, I. (2013). Antipathogenic activity of probiotics against Salmonella Typhimurium and Clostridium difficile in anaerobic batch culture systems: is it due to synergies in probiotic mixtures or the specificity of single strains? Anaerobe 24, 60-65. doi: 10.1016/j.anaerobe.2013.09.011

Thomson, A., Smart, K., Somerville, M. S., Lauder, S. N., Appanna, G., Horwood, J., et al. (2019). The ussing chamber system for measuring intestinal permeability in health and disease. BMC Gastroenterol. 19:98-98. doi: 10.1186/s12876-0191002-1004

Toki, S., Kagaya, S., Shinohara, M., Wakiguchi, H., Matsumoto, T., Takahata, Y., et al. (2009). Lactobacillus rhamnosus GG and Lactobacillus casei suppress Escherichia coli-induced chemokine expression in intestinal epithelial cells. Int. Arch. Allergy Immunol. 148, 45-58. doi: 10.1159/000151505

Trinder, M., Daisley, B. A., Dube, J. S., and Reid, G. (2017). Drosophila melanogaster as a high-throughput model for host-microbiota interactions. Front. Microbiol. 8:751. doi: 10.3389/fmicb.2017.00751

Tsilingiri, K., Sonzogni, A., Caprioli, F., and Rescigno, M. (2013). A novel method for the culture and polarized stimulation of human intestinal mucosa explants. J. Visual. Exp. JoVE e4368. doi: 10.3791/4368

Van de Wiele, T., Van den Abbeele, P., Ossieur, W., Possemiers, S., and Marzorati, M. (2015). "The simulator of the human intestinal microbial ecosystem (SHIME $\left.{ }^{\circledR}\right)$," in The Impact of Food Bioactives on Health: in Vitro and Ex Vivo Models, eds K. Verhoeckx, P. Cotter, I. López-Expósito, C. Kleiveland, 
T. Lea, A. Mackie, et al. (Cham: Springer International Publishing), 305-317. doi: 10.1007/978-3-319-16104-4_27

Van Krimpen, M., Hulst, M., der, M., Schokker, D., Savelkoul, H., Tijhaar, E., et al. (2014). Nutritional Intervention in Animals: Benchmarking of Strategies, Monitoring Biomarkers and Immune Competence. Wageningen: Wageningen UR Livestock Research.

Venditti, N., Vergalito, F., Magnifico, I., Cutuli, M. A., Pietrangelo, L., Cozzolino, A., et al. (2021). The lepidoptera Galleria mellonella "in vivo" model: a preliminary pilot study on oral administration of Lactobacillus plantarum (now Lactiplantibacillus plantarum). New Microbiol. 44, 42-50.

Vergauwen, H. (2015). "The IPEC-J2 cell line", in The Impact of Food Bioactives on Health: in vitro and Ex Vivo Models, eds K. Verhoeckx, P. Cotter, I. LópezExpósito, C. Kleiveland, T. Lea, A. Mackie, et al. (Cham: Springer International Publishing), 125-134. doi: 10.1007/978-3-319-16104-4_12

Vilela, S. F., Barbosa, J. O., Rossoni, R. D., Santos, J. D., Prata, M. C., Anbinder, A. L., et al. (2015). Lactobacillus acidophilus ATCC 4356 inhibits biofilm formation by C. albicans and attenuates the experimental candidiasis in Galleria mellonella. Virulence 6, 29-39. doi: 10.4161/21505594.2014.981486

Walter, J. (2008). Ecological role of lactobacilli in the gastrointestinal tract: implications for fundamental and biomedical research. Appl. Environ. Microbiol. 74, 4985-4996. doi: 10.1128/AEM.00753-758

Werner, K., Weitz, J., and Stange, D. E. (2016). Organoids as model systems for gastrointestinal diseases: tissue engineering meets genetic engineering. Curr. Pathobiol. Rep. 4, 1-9. doi: 10.1007/s40139-016-0100-z

Wiegerinck, C. L., Janecke, A. R., Schneeberger, K., Vogel, G. F., van Haaften-Visser, D. Y., Escher, J. C., et al. (2014). Loss of Syntaxin 3 causes variant microvillus inclusion disease. Gastroenterology 147, 65-68.e10. doi: 10.1053/j.gastro.2014. 04.002 .

Williamson, I. A., Arnold, J. W., Samsa, L. A., Gaynor, L., DiSalvo, M., Cocchiaro, J. L., et al. (2018). A high-throughput organoid microinjection platform to study gastrointestinal microbiota and luminal physiology. Cell Mol. Gastroenterol. Hepatol. 6, 301-319. doi: 10.1016/j.jcmgh.2018.05.004

Wong, C. N., Ng, P., and Douglas, A. E. (2011). Low-diversity bacterial community in the gut of the fruitfly Drosophila melanogaster. Environ. Microbiol. 13, 1889-1900. doi: 10.1111/j.1462-2920.2011.02511.x

Yang, X., Gao, X. C., Liu, J., and Ren, H. Y. (2017). Effect of EPEC endotoxin and bifidobacteria on intestinal barrier function through modulation of tolllike receptor 2 and toll-like receptor 4 expression in intestinal epithelial cell-18. World J. Gastroenterol. 23, 4744-4751. doi: 10.3748/wjg.v23.i26.4744
Zanni, E., Laudenzi, C., Schifano, E., Palleschi, C., Perozzi, G., Uccelletti, D., et al. (2015). Impact of a complex food microbiota on energy metabolism in the model organism Caenorhabditis elegans. Biomed. Res. Int. 2015:621709. doi: $10.1155 / 2015 / 621709$

Zhang, L., Dong, D., Jiang, C., Li, Z., Wang, X., and Peng, Y. (2015). Insight into alteration of gut microbiota in Clostridium difficile infection and asymptomatic C. difficile colonization. Anaerobe 34, 1-7. doi: 10.1016/j.anaerobe.2015.03. 008

Zhang, M., Liu, Y., and Chen, Y.-G. (2020). Generation of 3D human gastrointestinal organoids: principle and applications. Cell Regeneration 9:6. doi: 10.1186/s13619-020-00040-w

Zheng, H., Steele, M. I., Leonard, S. P., Motta, E. V. S., and Moran, N. A. (2018). Honey bees as models for gut microbiota research. Lab. Anim (NY) 47, 317-325. doi: 10.1038/s41684-018-0173-x

Zhou, M., Zhu, J., Yu, H., Yin, X., Sabour, P. M., Zhao, L., et al. (2014). Investigation into in vitro and in vivo models using intestinal epithelial IPEC-J2 cells and Caenorhabditis elegans for selecting probiotic candidates to control porcine enterotoxigenic Escherichia coli. J. Appl. Microbiol. 117, 217-226. doi: 10.1111/ jam. 12505

Zomer-van Ommen, D. D., Pukin, A. V., Fu, O., Quarles, van Ufford, L. H., Janssens, H. M., et al. (2016). Functional characterization of cholera toxin inhibitors using human intestinal organoids. J. Med. Chem. 59, 6968-6972. doi: 10.1021/acs.jmedchem.6b00770

Conflict of Interest: The authors were all employees of Danisco Sweeteners Oy, IFF Health \& Biosciences (Kantvik, Finland). IFF produces and markets probiotics.

Publisher's Note: All claims expressed in this article are solely those of the authors and do not necessarily represent those of their affiliated organizations, or those of the publisher, the editors and the reviewers. Any product that may be evaluated in this article, or claim that may be made by its manufacturer, is not guaranteed or endorsed by the publisher.

Copyright (c) 2022 Anjum, Laitila, Ouwehand and Forssten. This is an open-access article distributed under the terms of the Creative Commons Attribution License (CC BY). The use, distribution or reproduction in other forums is permitted, provided the original author(s) and the copyright owner(s) are credited and that the original publication in this journal is cited, in accordance with accepted academic practice. No use, distribution or reproduction is permitted which does not comply with these terms. 